\title{
Arsenic trioxide disrupts glioma stem cells via promoting PML degradation to inhibit tumor growth
}

\author{
Wenchao Zhou ${ }^{1}$, Lin Cheng ${ }^{2}$, Yu Shi ${ }^{1,3}$, Susan Q. Ke ${ }^{1}$, Zhi Huang ${ }^{1}$, Xiaoguang Fang $^{1}$, \\ Cheng-wei Chu ${ }^{1}$, Qi Xie ${ }^{1}$, Xiu-wu Bian ${ }^{3}$, Jeremy N. Rich ${ }^{1}$, Shideng Bao ${ }^{1}$ \\ ${ }^{1}$ Department of Stem Cell Biology and Regenerative Medicine, Lerner Research Institute, Cleveland Clinic, Cleveland, OH \\ 44195, USA \\ ${ }^{2}$ State Key Laboratory of Medical Genomics, Shanghai Institute of Hematology, Rui Jin Hospital, Shanghai Jiao Tong University, \\ Shanghai 200025, China \\ ${ }^{3}$ Institute of Pathology and Southwest Cancer Center, Southwest Hospital, Third Military Medical University, Chongqing \\ 400038, China
}

Correspondence to:

Shideng Bao, e-mail: baos@ccf.org

Keywords: glioblastoma, glioma stem cell, arsenic trioxide, PML, C-Myc

Received: July 23, $2015 \quad$ Accepted: October 01, $2015 \quad$ Published: October 14, 2015

\section{ABSTRACT}

Glioblastoma multiforme (GBM) is the most lethal brain tumor. Tumor relapse in GBM is inevitable despite maximal therapeutic interventions. Glioma stem cells (GSCs) have been found to be critical players in therapeutic resistance and tumor recurrence. Therapeutic drugs targeting GSCs may significantly improve GBM treatment. In this study, we demonstrated that arsenic trioxide $\left(\mathrm{As}_{2} \mathrm{O}_{3}\right)$ effectively disrupted $\mathrm{GSCs}$ and inhibited tumor growth in the GSC-derived orthotopic xenografts by targeting the promyelocytic leukaemia ( $P M L) . \mathrm{As}_{2} \mathrm{O}_{3}$ treatment induced rapid degradation of PML protein along with severe apoptosis in GSCs. Disruption of the endogenous PML recapitulated the inhibitory effects of $\mathrm{As}_{2} \mathrm{O}_{3}$ treatment on GSCs both in vitro and in orthotopic tumors. Importantly, $\mathrm{As}_{2} \mathrm{O}_{3}$ treatment dramatically reduced GSC population in the intracranial GBM xenografts and increased the survival of mice bearing the tumors. In addition, $\mathrm{As}_{2} \mathrm{O}_{3}$ treatment preferentially inhibited cell growth of GSCs but not matched non-stem tumor cells (NSTCs). Furthermore, $\mathrm{As}_{2} \mathrm{O}_{3}$ treatment or PML disruption potently diminished c-Myc protein levels through increased poly-ubiquitination and proteasome degradation of c-Myc. Our study indicated a potential implication of $\mathrm{As}_{2} \mathrm{O}_{3}$ in GBM treatment and highlighted the important role of $\mathrm{PML} / \mathrm{C}-\mathrm{Myc}$ axis in the maintenance of GSCs.

\section{INTRODUCTION}

Glioblastoma multiforme (GBM), classified as the grade IV astrocytoma, is the most lethal and common type of primary brain tumor. With a crude annual incidence of 3 per 100,000 individuals, GBM predicts a median survival of less than 16 months associated with very poor life quality [1]. Despite aggressive therapies including surgical resection, radiation and chemotherapy, tumor relapse is a common event in GBM patients [1]. Recent studies indicate that a subset of GBM tumor cells with stem cell-like properties, named glioma stem cells (GSCs), play a critical role in therapeutic resistance, tumor recurrence and malignant progression [2-7]. At the apex of the differentiation hierarchy of glioma cells, GSCs have the capacities to self-renew, differentiate, and recapitulate the whole tumor [8]. GSCs showed potent tumor formation ability in immunocompromised mice [2, 3]. GSCs are also more resistant to irradiation relative to matched non-stem tumor cells (NSTCs) $[3,9,10]$. An increase of GSC population was observed in vivo after chemoradiation treatment, further supporting the involvement of GSCs in therapeutic resistance and the resultant tumor relapse [3, 11-13]. In addition, GSCs promote tumor angiogenesis, pericyte derivation, cancer invasion, and immune evasion, all contributing to the treatment failure $[6,14-17]$. Therefore, efficient elimination of the GSC population is a critical step to achieve successful GBM treatment. 
Multiple drugs have been applied in GBM treatment, but most of them generate only mild and temporary beneficial outcomes. Addition of Temozolomide (TMZ) to ionic irradiation (IR) statistically improves the prognosis of newly diagnosed GBM patients, but the overall survival rate after treatment is still very poor [18]. The limited effect of TMZ treatment can largely be ascribed to the GSC population. Genetic depletion of the Nestin-positive GSCs restored the response of GBM tumors to TMZ in the genetically engineered mouse model [7]. In fact, exposure to TMZ resulted in expansion of GSC population either by selective amplification of GSCs or by phenotypic shift of non-stem tumor cells to a GSC-like state [19]. In addition, the anti-VEGF-A monoclonal antibody bevacizumab targeting tumor vascularization has a transient inhibition on GBM tumor growth, but the effect is greatly attenuated in the GSC population due to the VEGFR2-Neuropilin-1 autocrine loop [20]. Furthermore, inhibition of vessel formation will cause hypoxia which in the long run will facilitate GSC maintenance or expansion [21-23]. Although numerous efforts have been put in exploration of new drugs targeting GSCs to control GBM tumors, so far no obvious advance has been made.

Arsenic trioxide $\left(\mathrm{As}_{2} \mathrm{O}_{3}\right)$ is a small molecular drug approved by FDA for leukemia treatment [24]. During the development of acute promyelocytic leukemia (APL), the PML-RAR $\alpha$ fusion protein has been demonstrated to underlie the abnormal transcription and the consequent rapid growth of tumor cells [25]. Administration of $\mathrm{As}_{2} \mathrm{O}_{3}$ in leukemia induces the ubiquitination-mediated degradation of the PML-RAR $\alpha$ fusion protein via multiple pathways and manifests substantial therapeutic effects [26-29]. Furthermore, elimination of PML-RAR $\alpha$ by $\mathrm{As}_{2} \mathrm{O}_{3}$ treatment clears leukemia-initiating cells in mouse APL, suggesting the potential of $\mathrm{As}_{2} \mathrm{O}_{3}$ in targeting cancer stem cells [30]. So far, no PML-RAR $\alpha$ mutant has been reported in GBM. However, recent studies demonstrated that the $\mathrm{As}_{2} \mathrm{O}_{3}$ target PML itself plays a critical role in the maintenance of leukemia initiating cells in chronic myeloid leukemia [31]. This discovery indicates the potential application of $\mathrm{As}_{2} \mathrm{O}_{3}$ in treating other cancers such as GBM bearing cancer stem cells. In fact, preliminary studies suggested the inhibitory effect of $\mathrm{As}_{2} \mathrm{O}_{3}$ on in vitro cultured glioma tumour-spheres [32], but the consequences of $\mathrm{As}_{2} \mathrm{O}_{3}$ administration on GSCderived GBMs in vivo as well as the underlying molecular mechanisms remained largely unknown.

Inspired by the new breakthrough in targeting cancer stem cells by $\mathrm{As}_{2} \mathrm{O}_{3}$ in several types of leukemia $[30,31]$, we examined the effect of $\mathrm{As}_{2} \mathrm{O}_{3}$ on GSCs in vitro and in GSC-derived xenografts. $\mathrm{As}_{2} \mathrm{O}_{3}$ treatment showed a dramatic inhibition on GSC growth in culture and tumor progression in GBM xenografts. Moreover, $\mathrm{As}_{2} \mathrm{O}_{3}$ treatment diminished PML protein in GSCs.
Consistently, knockdown of PML had similar outcomes as $\mathrm{As}_{2} \mathrm{O}_{3}$ treatment, suggesting that $\mathrm{As}_{2} \mathrm{O}_{3}$ targets GSCs via degradation of PML protein. In contrast, $\mathrm{As}_{2} \mathrm{O}_{3}$ treatment displayed negligible effect on non-stem glioma cells. Finally, we found that c-Myc is one of the key downstream effectors in response to the $\mathrm{As}_{2} \mathrm{O}_{3}$-mediated PML degradation in GSCs. Our findings indicate that ablation of cancer stem cells in GBM by $\mathrm{As}_{2} \mathrm{O}_{3}$ treatment may have therapeutic potential and clinical implication in the control of this lethal cancer.

\section{RESULTS}

\section{$\mathrm{As}_{2} \mathrm{O}_{3}$ treatment inhibited GSC sphere formation and tumor growth}

To examine the putative effect of $\mathrm{As}_{2} \mathrm{O}_{3}$ treatment on GSCs in vitro, we performed the tumorsphere formation assays with GSCs isolated from GBM surgical specimens or xenografts. Sorted GSCs (T4121 or T387) were cultured in 6-well plates and treated with various doses of $\mathrm{As}_{2} \mathrm{O}_{3}$. Treatment with $\mathrm{As}_{2} \mathrm{O}_{3}(1-4 \mu \mathrm{M})$ effectively inhibited GSC sphere formation and caused a significant decrease both in sphere size and number (Figure 1A-1C). In detail, treatment of GSCs with $\mathrm{As}_{2} \mathrm{O}_{3}$ at $2 \mu \mathrm{M}$ resulted in loss of $50-70 \%$ spheres and the treatment with $4 \mu \mathrm{M} \mathrm{As}_{2} \mathrm{O}_{3}$ markedly inhibited GSC sphere formation (Figure 1A-1C). Even at the dosage of $0.5 \mu \mathrm{M}$, the effect of $\mathrm{As}_{2} \mathrm{O}_{3}$ treatment was very significant with a $50 \%$ decrease on sphere size (Figure 1C). Consistently, cell titer assay confirmed that $\mathrm{As}_{2} \mathrm{O}_{3}$ treatment $(1-4 \mu \mathrm{M})$ significantly suppressed GSC growth in vitro (data not shown). Thus, $\mathrm{As}_{2} \mathrm{O}_{3}$ treatment has potent inhibitory effect on GSC tumorsphere formation and growth in vitro.

We then examined the impact of $\mathrm{As}_{2} \mathrm{O}_{3}$ administration on tumor growth of the GSC-derived orthotopic xenografts. Mice bearing GBM xenografts derived from luciferase-expressing GSCs (T387) were treated with $\mathrm{As}_{2} \mathrm{O}_{3}(5 \mu \mathrm{g} / \mathrm{g})[33,34]$ or vehicle control daily from the fourth day after GSC implantation. In vivo tumor growth after treatment was determined by the luciferase activity in tumors at indicated time points. While the initiating tumor sizes were similar at Day 4 after GSC implantation, the delayed tumor growth was detected in the $\mathrm{As}_{2} \mathrm{O}_{3}$-treated group, which was represented by the significant less luciferase signal in mouse brains in $\mathrm{As}_{2} \mathrm{O}_{3}$-treated mice than control mice at Day 10 and Day 18 (Figure 1D and 1E). As a result of the inhibited tumor growth, mice treated with $\mathrm{As}_{2} \mathrm{O}_{3}$ also displayed a significantly extended survival relative to the control mice (Figure 1F). These data demonstrate that $\mathrm{As}_{2} \mathrm{O}_{3}$ treatment significantly inhibited tumor growth of GSC-derived xenografts and increased survival of animals bearing the GBM xenografts. 

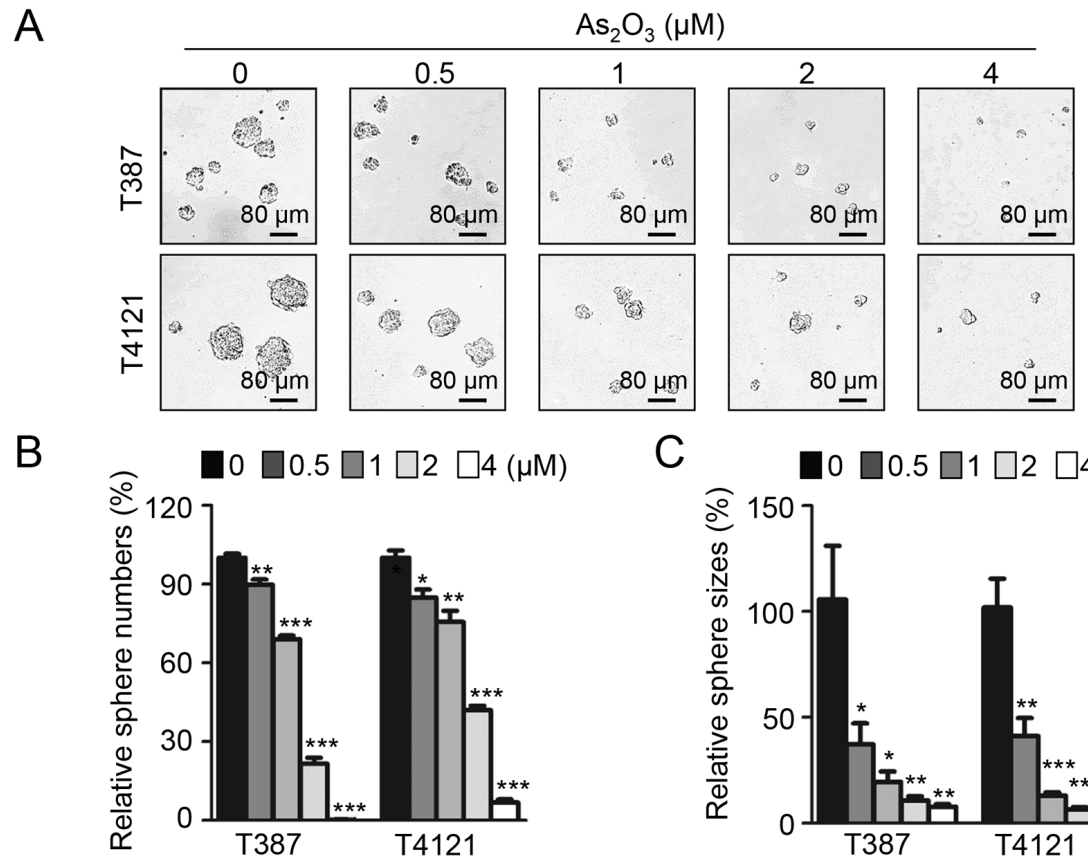

C
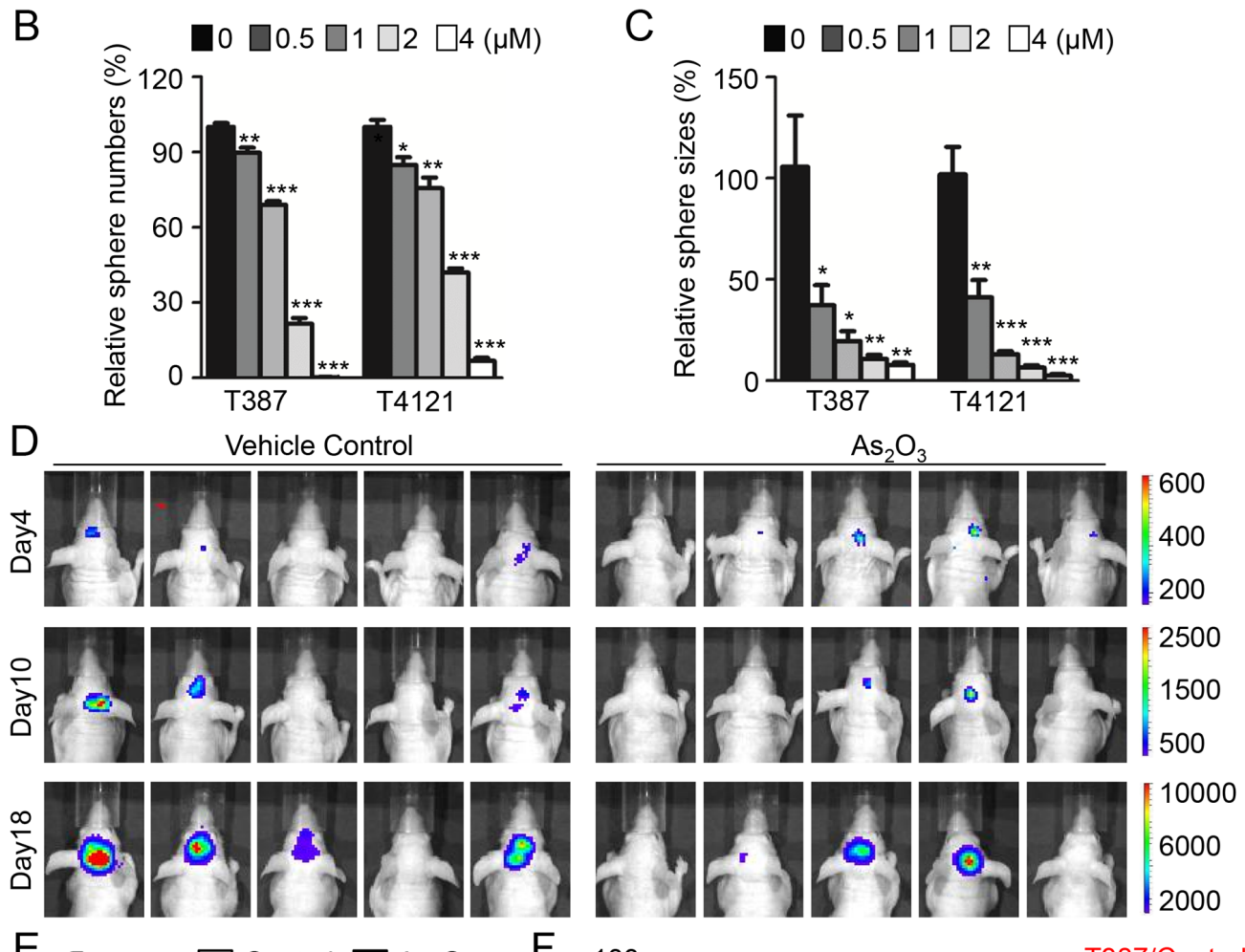

$\mathrm{E}$
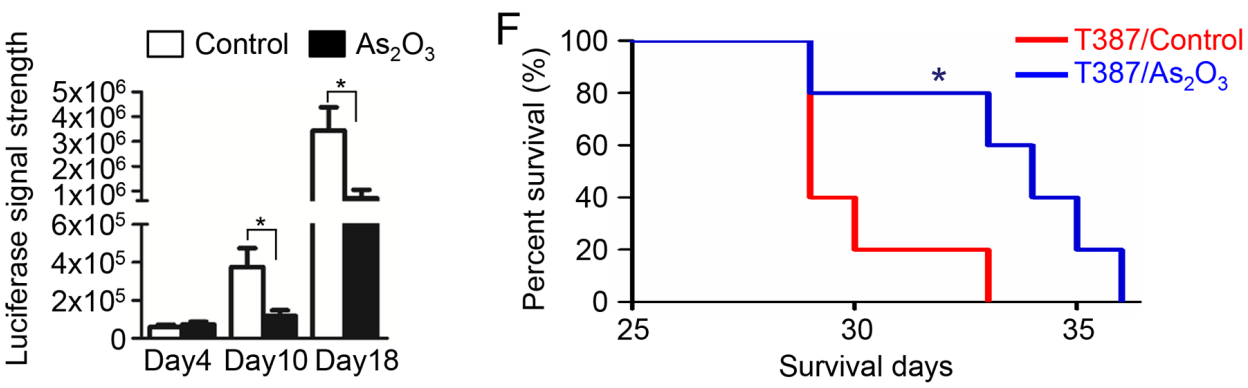

Figure 1: $\mathrm{As}_{2} \mathrm{O}_{3}$ treatment effectively inhibited GSC tumorsphere formation and tumor growth and significantly increased survival of mice bearing GSC-derived xenografts. A. Representative images of GSC tumorspheres showing that $\mathrm{As}_{2} \mathrm{O}_{3}$ treatment suppressed GSC tumorsphere formation in a dose-dependent manner. T387 or T4121 GSCs were planted in 96 well plates at the density of 2,000 cells per well for 24 hours, and then treated with varied concentration of $\mathrm{As}_{2} \mathrm{O}_{3}$ as indicated for 48 hours. B, C. Statistical bar graphs showing the inhibitory effects of different doses of $\mathrm{As}_{2} \mathrm{O}_{3}$ treatment on GSC tumorsphere numbers B. and sizes C. Data represent three independent experiments. ${ }^{*} p<0.05 ;{ }^{* *} p<0.001 ;{ }^{* * *} p<0.001$ (mean \pm s.e.m.; two tailed unpaired $t$-test). D. In vivo bioluminescent imaging of GSC-derived intracranial tumor growth in the $\mathrm{As}_{2} \mathrm{O}_{3}$ treated and control mice. T387 GSCs (500 cells) transduced with luciferase were transplanted into brains of immunocompromised mice to establish orthotopic GBM xenografts. Mice were treated with $\mathrm{As}_{2} \mathrm{O}_{3}(5 \mu \mathrm{g} / \mathrm{g})$ or vehicle control daily through IP injection starting day 4 after GSC transplantation. Representative images of luciferase signal in mouse brains on Days 4, 10 and 18 after GSC implantation were shown. E. Bar graphs of the average signal of luciferase activity in $\mathrm{As}_{2} \mathrm{O}_{3}$ treated and control mouse brains in D showing that $\mathrm{As}_{2} \mathrm{O}_{3}$ treatment significantly inhibited GSC tumor growth. * $p<0.05$ (mean \pm s.e.m.; two tailed unpaired $t$-test). F. Kaplan-Meier survival curves of mice bearing GSC-derived xenografts after $\mathrm{As}_{2} \mathrm{O}_{3}$ or vehicle treatment. Logrank analysis revealed the significant extension of mouse survival in $\mathrm{As}_{2} \mathrm{O}_{3}$-treated group relative to the control group. $(n=5$ for each group; $*: p<0.05)$. 


\section{$\mathrm{As}_{2} \mathrm{O}_{3}$ treatment reduced PML protein and promoted apoptosis in GSCs}

Previous reports demonstrated that $\mathrm{As}_{2} \mathrm{O}_{3}$ treatment triggered an immediate downregulation of PML [26, 27], therefore we explored the dynamic of PML protein in GSCs in response to $\mathrm{As}_{2} \mathrm{O}_{3}$ treatment. A time course study showed that $\mathrm{As}_{2} \mathrm{O}_{3}$ treatment induced a gradual loss of PML protein in T387 and T4121 GSCs (Figure 2A and 2B, top panels). Meanwhile, the cleaved PARP, an apoptotic marker, increased along with the PML reduction during the course of $\mathrm{As}_{2} \mathrm{O}_{3}$ treatment (Figure 2A and 2B, middle panels), suggesting the induction of GSC apoptosis by $\mathrm{As}_{2} \mathrm{O}_{3}$ treatment. This result was further confirmed by immunofluorescent staining of another apoptotic marker, the cleaved Caspase-3. As shown in Figure 2C, $\mathrm{As}_{2} \mathrm{O}_{3}$ treatment resulted in an increase of the cleaved Caspase-3 along with a gradual decrease of PML protein levels. These data indicate that induction of GSC apoptosis may underlie the inhibited cell growth after $\mathrm{As}_{2} \mathrm{O}_{3}$ treatment. As $\mathrm{As}_{2} \mathrm{O}_{3}$ treatment in vivo inhibited GSC tumor growth, we further examined the effect of $\mathrm{As}_{2} \mathrm{O}_{3}$ on PML protein and apoptosis in GSC-derived xenografts. Immunofluorescent staining demonstrated a significant decrease of PML signals accompanied by an increase of the cleaved Caspase-3 staining in the $\mathrm{As}_{2} \mathrm{O}_{3}$-treated xenografts relative to the control xenografts (Figure 2D and 2E). Collectively, these data demonstrate that $\mathrm{As}_{2} \mathrm{O}_{3}$ treatment reduced PML protein and induces apoptotic cell death in vitro and in GSC-derived xenografts.

\section{PML knockdown in GSCs mimics $\mathrm{As}_{2} \mathrm{O}_{3}$ treatment in vitro and in vivo}

As $\mathrm{As}_{2} \mathrm{O}_{3}$ treatment led to PML reduction and induced apoptosis in GSCs, we next sought to determine whether $\mathrm{As}_{2} \mathrm{O}_{3}$ exerts its effects on GSCs through downregulation of PML. To address this issue, we examined if disruption of PML by shRNA in GSCs shows similar effects as $\mathrm{As}_{2} \mathrm{O}_{3}$ treatment. Two non-overlapping shRNAs targeting PML, named as shPML-P66 and shPML-P97, were applied in this study to mediate PML knockdown. Immunoblot validated the efficiency of the shRNAs in GSCs (T387 and D456) with more than $80 \%$ decrease of endogenous PML protein (Figure 3A, Supplementary Figure S1A). Tumorsphere formation assays of the GSCs infected with non-targeting (shNT) or shPML lentiviruses showed a significant inhibition of GSC sphere formation after PML knockdown (Figure 3B and 3C, Supplementary Figure S1B). The inhibitory effect of PML disruption on GSC growth was further quantified by cell titer assays. Interestingly, PML knockdown not only suppressed GSC proliferation but also caused severe cell death, which was demonstrated by the downward cell titer curves in cells infected with shPML viruses (Figure 3D,
Supplementary Figure S1C). Staining of the apoptotic marker Annexin V confirmed the occurrence of massive apoptosis in GSCs two days after infection of shPML viruses (Figure $3 \mathrm{E}$ and $3 \mathrm{~F}$ ), suggesting that increased GSC cell death may be a result of apoptosis induced by PML disruption. Furthermore, disruption of PML by the shRNAs severely impaired tumor growth of the GSCderived xenografts (Figure 4A). As a consequence, mice bearing the GSC-derived xenografts expressing shPML had a significantly extended survival relative to the control group (Figure 4B, Supplementary Figure S1D). Taken together, PML disruption resulted in increased apoptosis and reduced tumorigenic capacity of GSCs, which recapitulates the effects of $\mathrm{As}_{2} \mathrm{O}_{3}$ treatment in vitro and in vivo.

\section{$\mathrm{As}_{2} \mathrm{O}_{3}$ treatment reduced GSC population in GBM xenografts}

As $\mathrm{As}_{2} \mathrm{O}_{3}$ treatment mimics PML disruption to induce GSC apoptosis in vitro, we further investigated the effect of $\mathrm{As}_{2} \mathrm{O}_{3}$ treatment on GSC population in GSC-derived xenografts. Immunofluorescent staining of GSC markers SOX2 and OLIG2 demonstrated that $\mathrm{As}_{2} \mathrm{O}_{3}$ treatment dramatically reduced GSC population in the T387 and T4121 GSC-derived xenografts (Figure 5A-5D, Supplementary Figure S2A-S2D). GSCs express high levels of the angiogenic factor VEGF to promote tumor angiogenesis $[16,35]$, and $\mathrm{As}_{2} \mathrm{O}_{3}$-induced GSC disruption in the orthotopic tumors is supposed to influence the tumor vascularization. We next examined whether $\mathrm{As}_{2} \mathrm{O}_{3}$-induced reduction of GSCs impacts vessel density in GBM xenografts. Immunofluorescent staining of the vessel endothelial cell marker Glut1 indicated that $\mathrm{As}_{2} \mathrm{O}_{3}$ treatment significantly reduced vessel density in GSC-derived xenografts (Figure 5E and 5F). Thus, $\mathrm{As}_{2} \mathrm{O}_{3}$ treatment reduced GSC population in GBMs, which may in turn attenuate angiogenic factors produced by GSCs to inhibit tumor vascularization. Consistently, $\mathrm{As}_{2} \mathrm{O}_{3}$ treatment reduced PML protein and SOX2-positive cells (GSCs) in xenografts derived from two GSC lines (T387 and T4121) (Figure 5G, Supplementary Figure S2E). Although some cancer cells in the $\mathrm{As}_{2} \mathrm{O}_{3}$ treated xenografts remained to be SOX2 positive (GSCs), these SOX2 signal almost overlapped with the PML staining (Figure 5G, Supplementary Figure S2E), and the majority of SOX+ cells (GSCs) were also PML-positive (Figure 5H, Supplementary Figure S2F). Collectively, these data suggested that degradation of PML triggered by $\mathrm{As}_{2} \mathrm{O}_{3}$ resulted in the reduction of GSC population after $\mathrm{As}_{2} \mathrm{O}_{3}$ treatment in vivo, supporting a critical role of PML in the maintenance of GSCs in GBM tumors. 
A

\begin{tabular}{cccccc}
\multicolumn{4}{c}{$\mathrm{T} 387 \mathrm{GSCs}$} & + & $\mathrm{As}_{2} \mathrm{O}_{3}$ \\
\hline 0 & 1 & 2 & 3 & 4 & 5 (Day)
\end{tabular}

PML
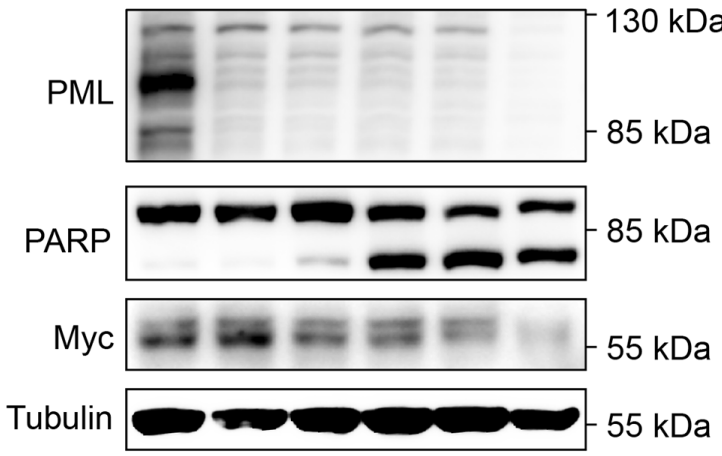

$-85 \mathrm{kDa}$

$55 \mathrm{kDa}$

$55 \mathrm{kDa}$
B
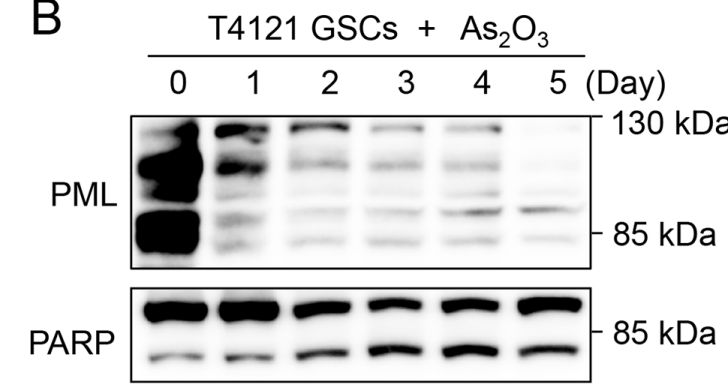

Myc 23 :

Tubulin

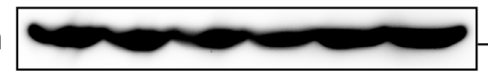

$55 \mathrm{kDa}$

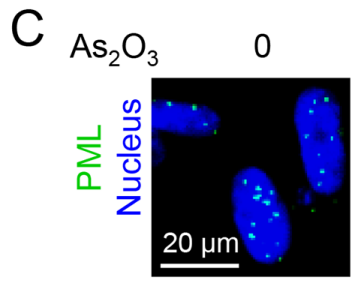

1

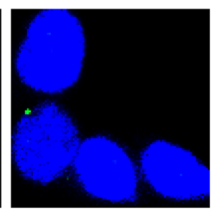
2
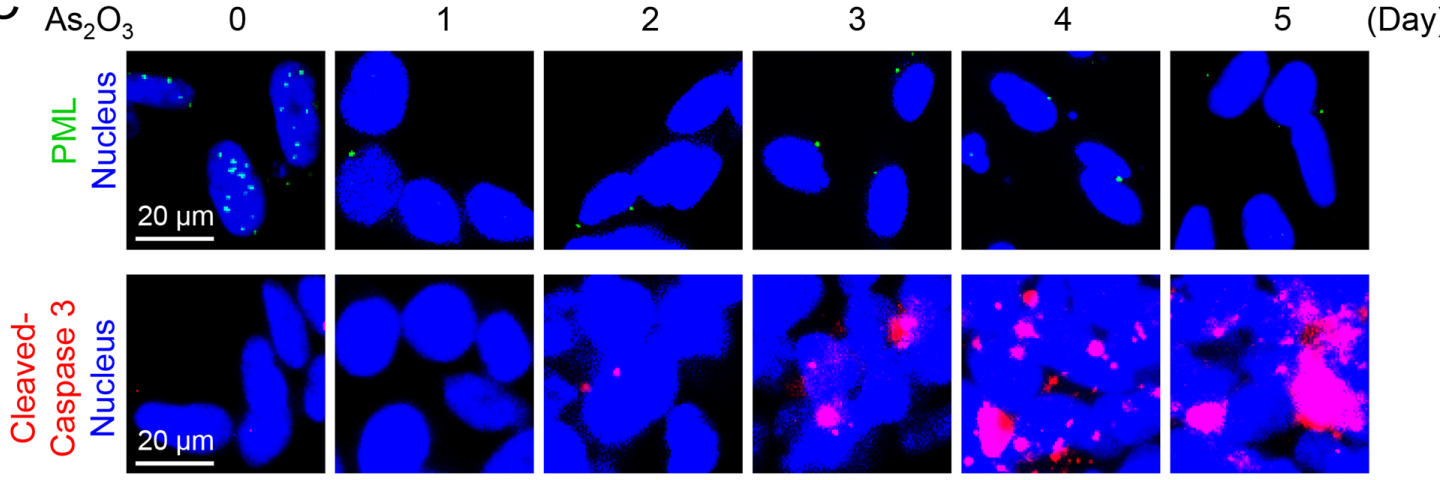

D
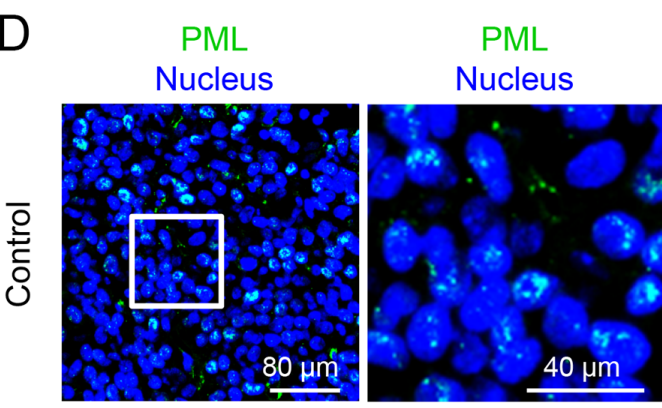

Cleaved-Caspase 3

E

Control

$+\mathrm{As}_{2} \mathrm{O}_{3}$
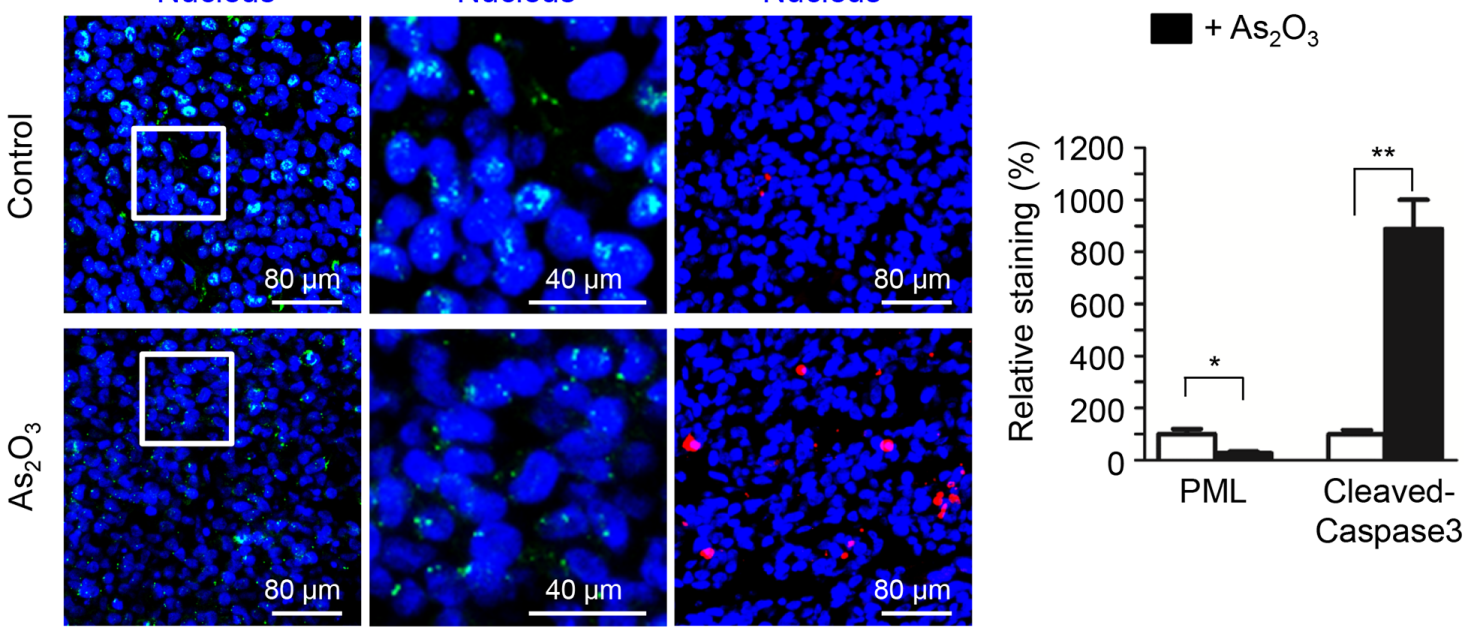

Figure 2: $\mathrm{As}_{2} \mathrm{O}_{3}$ treatment reduced PML protein and promoted apoptosis in GSCs. A, B. Immunoblot analysis of GSCs (T387 and T4121) treated with $\mathrm{As}_{2} \mathrm{O}_{3}$ for varied duration (0-5 days) as indicated. A decrease of PML protein levels along with an increase of the apoptotic marker cleaved PARP was detected after $\mathrm{As}_{2} \mathrm{O}_{3}$ treatment. C. Immunofluorescent staining of PML and cleaved Caspase-3 (an apoptotic marker) in GSCs (T387) treated with $\mathrm{As}_{2} \mathrm{O}_{3}$ for varied duration. A decreased PML signal (green) along with an increased cleaved Caspase-3 (red) was detected after $\mathrm{As}_{2} \mathrm{O}_{3}$ treatment. D. Immunofluorescent staining of PML (green) and cleaved Caspase-3 (red) on frozen sections of GSC-derived intracranial xenografts (T387) treated with $\mathrm{As}_{2} \mathrm{O}_{3}$ or vehicle control. The sections were counterstained with DAPI for nuclei (blue). $\mathrm{As}_{2} \mathrm{O}_{3}$ treatment resulted in decreased PML level (green) and increased cleaved-Caspase-3 signal (red). E. Statistical bar graphs showing a significant decrease of PML signal and the significant increase of cleaved-Caspase- 3 in $\mathrm{As}_{2} \mathrm{O}_{3}$-treated xenografts relative to the control tumors. PML signals were quantified according to the size of the area stained by the anti-PML antibody. Cleaved-Caspase- 3 signals were quantified according to the numbers of dots stained by the corresponding antibody. Image J was applied for the quantification. $* p<0.05 ;{ }^{*} p<0.01$ (mean \pm s.e.m.; two tailed unpaired $t$-test). 
A
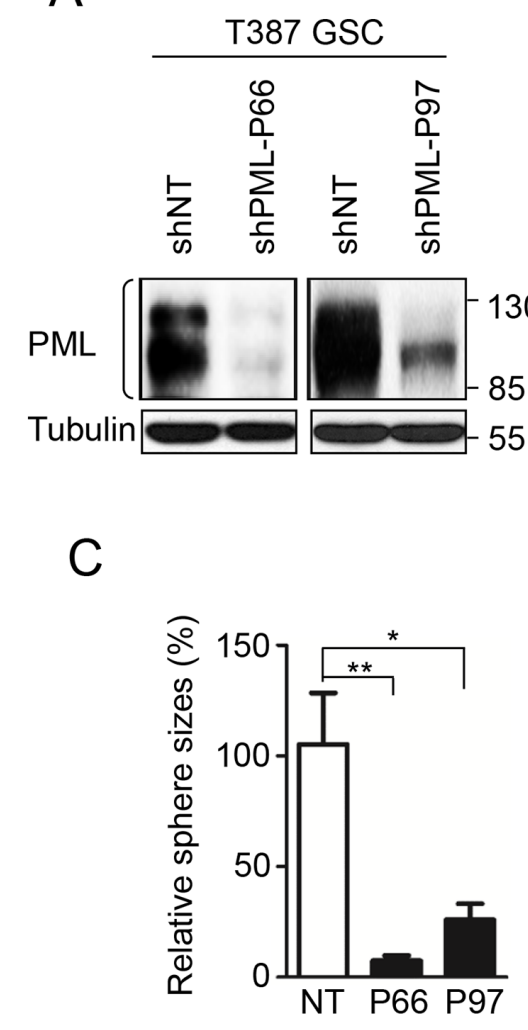

E

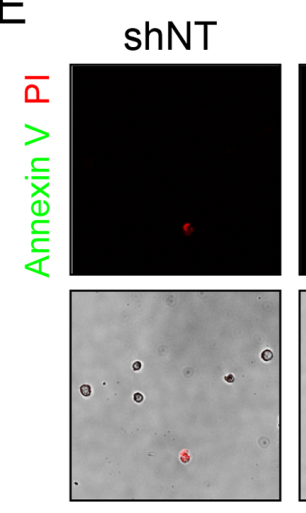

$\mathrm{B}$

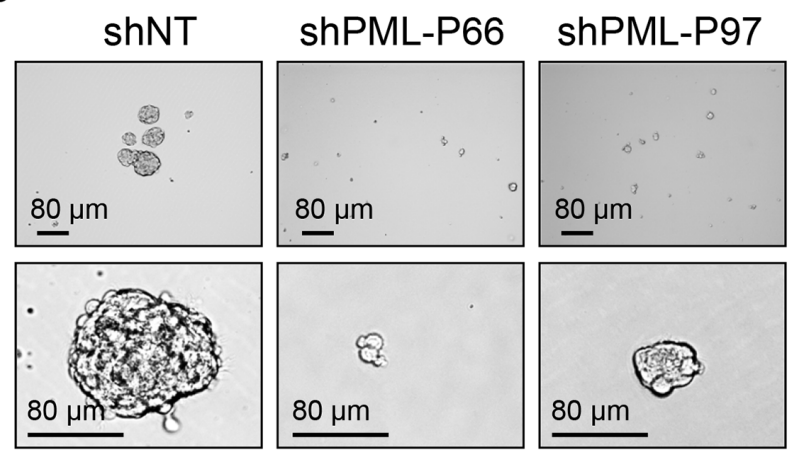

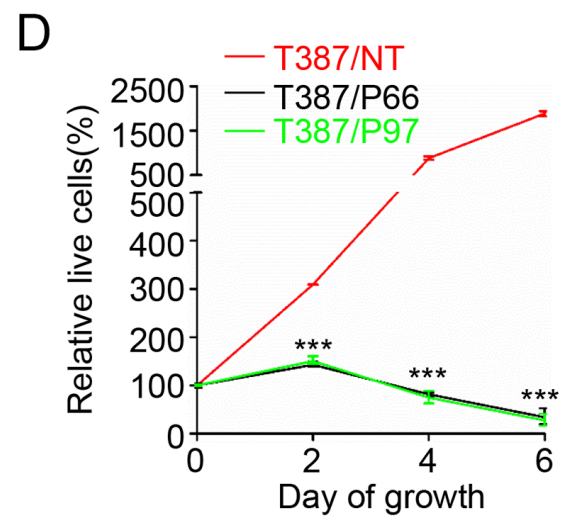

$\mathrm{F}$

Figure 3: Knock-down of PML in GSCs mimics $\mathrm{As}_{2} \mathrm{O}_{3}$ treatment to inhibit GSC growth in vitro. A. Immunoblot analysis showing the efficiency of PML knockdown in GSCs by shPML lentiviruses. Both shPML-P66 and shPML-P97 infection reduced more than 80 percent of endogenous PML in GSCs. B. Knock-down of PML reduced GSC sphere formation. GSCs (T387) were infected with shPML or shNT lentiviruses for 24 hours, and then planted into 96 well plates at the concentration of 2,000 cells per well. Representative images showing GSC spheres 96 hours after lentiviral infection. A dramatic reduction of GSC sphere size was observed after PML knockdown. C. Statistical bar graphs showing a significant decrease in tumorsphere sizes of shPML-expressing GSCs relative to shNT-expressing GSCs. ${ }^{*} p<0.05 ;{ }^{* *} p<0.01$ (mean \pm s.e.m.; two tailed unpaired $t$-test). D. Cell titer assays showing cell growth of GSCs transduced shPML or shNT control. GSCs were infected with shPML or shNT lentiviruses for 24 hours, and then split into 96 well plates at the concentration of 2,000 cells per well. Cell titer was determined by the Glo luminescent cell viability assay kit (Promega) at the indicated time points. Disruption of PML significantly inhibited GSC growth and induced cell death. ${ }^{* * *} p<0.001$ (mean \pm s.e.m.; two tailed unpaired $t$-test). E. Annexin V (an apoptosis marker) staining of GSCs transduced with shPML or shNT. 48 hours after infection with shPML or shNT lentiviruses, cells were trypsinized and stained with Annexin V apoptosis detection kit (BD Pharmingen). GSCs transduced with shPML showed more apoptotic cells with Annexin V staining than the control GSCs with shNT. F. Statistical bar graphs showing a significant increase of apoptosis in shPML-expressing GSCs relative to the shNT-expressing GSCs measured by Annexin V staining. ${ }^{* *} p<0.01$ (mean \pm s.e.m.; two tailed unpaired $t$-test). 

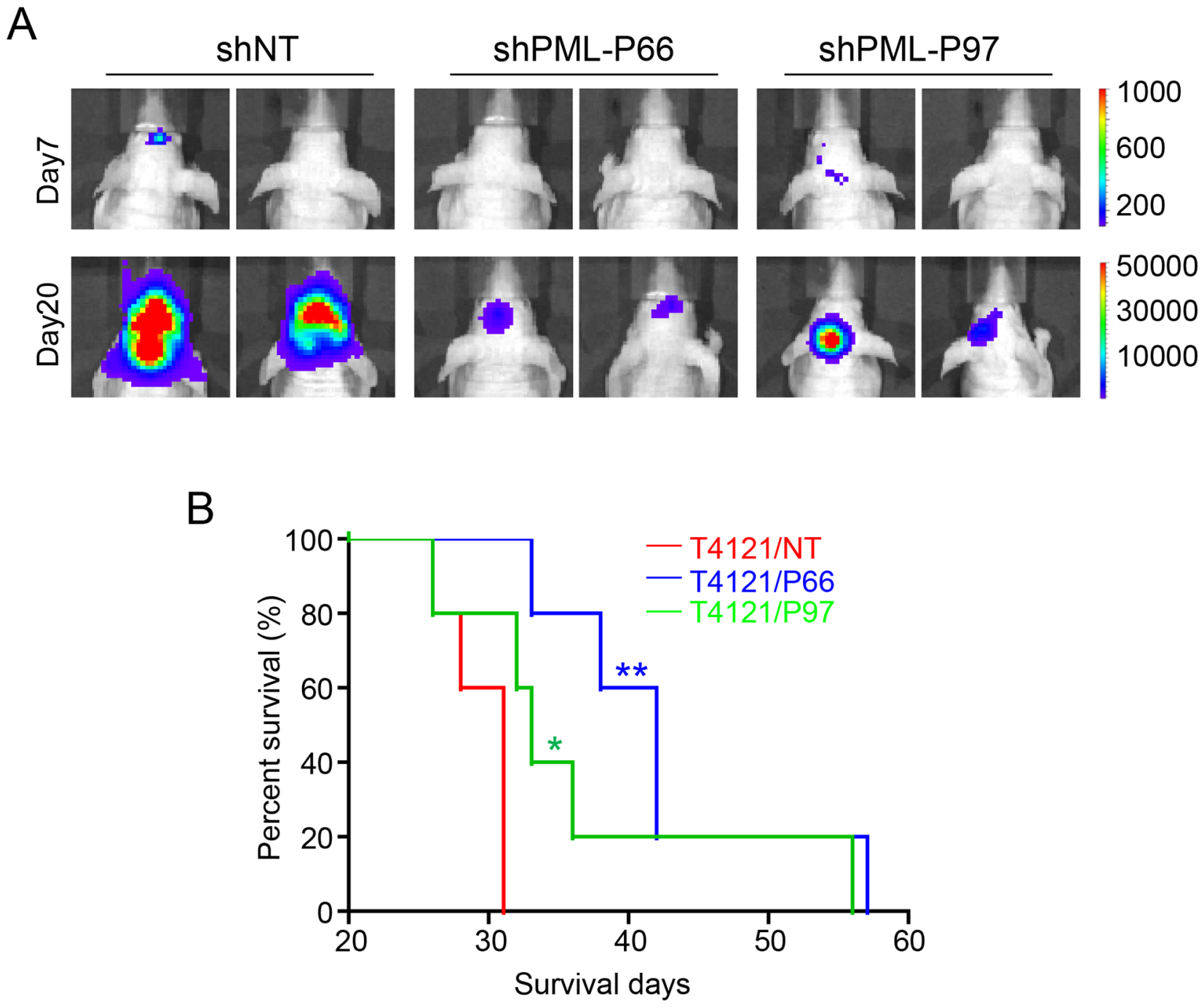

Figure 4: Disruption of PML in GSCs inhibits GSC-derived GBM tumor growth in vivo. A. In vivo bioluminescent imaging to monitor the tumor growth of orthotopic xenografts derived from shPML- and shNT-expressing GSCs. GSCs (T387) transduced with shPML or shNT and luciferase were transplanted into brains of immunocompromised mice $(5,000$ cells/mouse) through intracranial injection. Luciferase signals were monitored at indicated time points after GSC transplantation. Representative luciferase images on days 7 and 20 showed that much weaker luciferase signals were detected in xenografts derived from shPML-expressing GSCs than that derived from shNT-expressing GSCs, indicating a retarded tumor growth by disruption of PML. B. Kaplan-Meier survival curves of mice bearing GBM xenografts derived from shPML- or shNT- expressing GSCs. Mice intracranially implanted with shPML- and shNT-expressing GSCs were monitored and maintained until the manifestation of neurological signs. Logrank analysis revealed a significant extension of survival in groups of mice bearing shPMLGSC-derived xenografts relative to the control mice bearing shNT-GSC-derived xenografts. $\left(n=5\right.$ mice for each group; $\left.{ }^{*} p<0.05 ; * * p<0.01\right)$.

\section{GSCs and matched NSTCs displayed distinct PML distributions and showed different responses to $\mathrm{As}_{2} \mathrm{O}_{3}$ treatment}

Since disruption of PML effectively induced apoptosis of GSCs, we sought to determine whether the effect of $\mathrm{As}_{2} \mathrm{O}_{3}$ on GSCs is preferential. PML has been shown to be the organizer for certain specific nuclear structures, i.e. nuclear bodies, which are punctate small dots within nuclei. Nuclear bodies are thought to be transcriptional hot spots and may be involved in many critical cellular processes [36]. Thus, PML distribution and nuclear pattern are closely associated with its functional status [37-39]. To further address the functional significance of PML in GSCs, we examined PML distribution in GSCs and matched NSTCs by immunofluorescent staining. Grossly, PML signals were exclusively detected in nuclei in both GSCs and NSTCs. However, while PML nuclear dots appeared to be smaller and sharper in GSCs, the PML dots were larger and vaguer in NSTCs (Supplementary Figure S3). The smeared PML distribution in NSTCs may represent a less organized status.

As GSCs and NSTCs displayed different patterns of PML nuclear bodies, we examined whether GSCs and 

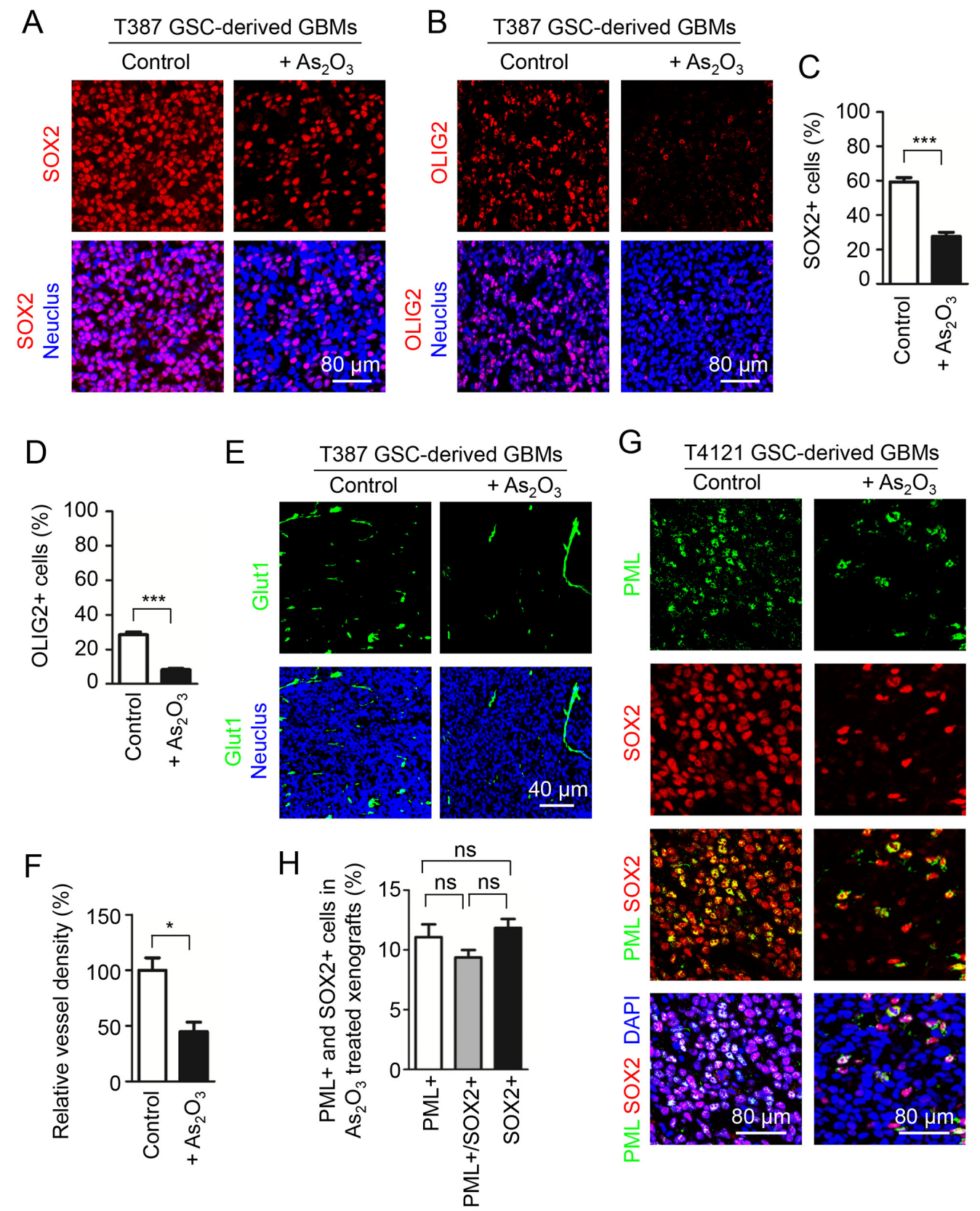

Figure 5: $\mathrm{As}_{2} \mathrm{O}_{3}$ treatment reduced PML protein and GSC population in vivo. A, B. Immunofluorescent staining of the GSC markers SOX2 (A, in red) or OLIG2 (B, in red) on frozen sections of GSC-derived intracranial xenografts from mice treated with $\mathrm{As}_{2} \mathrm{O}_{3}$ or the vehicle control. 4 days after GSC transplantation, mice bearing the GSC-derived xenografts (T387) were treated with $\mathrm{As}_{2} \mathrm{O}_{3}(5 \mu \mathrm{g} / \mathrm{g}$ ) or vehicle control daily through IP injection for 15 days, and then mouse brains bearing the tumors were harvested and sectioned for the immunofluorescence. $\mathrm{As}_{2} \mathrm{O}_{3}$ treatment markedly reduced SOX2+ or OLIG2+ (GSCs) in the GSC-derived xenografts. C, D. Statistical bar graphs showing a significant decrease in SOX2+ C. or OLIG2+ D. population in the $\mathrm{As}_{2} \mathrm{O}_{3}$-treated xenografts relative to the control xenografts. ${ }^{* * *} p<0.001$ (mean \pm s.e.m.; two tailed unpaired $t$-test). E. Immunofluorescent staining of the endothelial marker Glut1 detecting blood vessels (in green) on frozen sections of xenografts from mice treated with $\mathrm{As}_{2} \mathrm{O}_{3}$ or vehicle control. Sections were counterstained with DAPI to label nuclei (blue). Xenografts from mice treated with $\mathrm{As}_{2} \mathrm{O}_{3}$ showed lower vessel density relative to the control xenografts. F. Statistical bar graphs showing a significant decrease in vessel density (Glut1+) in the $\mathrm{As}_{2} \mathrm{O}_{3}$-treated xenografts relative to the control xenografts. ${ }^{*} p<0.05$ (mean \pm s.e.m.; two tailed unpaired $t$-test). G. Immunofluorescent staining of PML (in green) and the GSC marker $\mathrm{SOX} 2$ (in red) in T4121 GSC-derived xenografts from mice treated with $\mathrm{As}_{2} \mathrm{O}_{3}$ or vehicle control. Frozen tumor sections were counterstained with DAPI (blue). $\mathrm{As}_{2} \mathrm{O}_{3}$-treated xenografts displayed much fewer PML+ cells and SOX2+ cells (GSCs). Noticeably, most PML staining signal overlapped with SOX2 signal in GSCs in $\mathrm{As}_{2} \mathrm{O}_{3}$-treated xenografts. H. Bar graphs showing percentages of PML positive cells and the SOX2 positive GSC population in xenografts treated with $\mathrm{As}_{2} \mathrm{O}_{3}$. The majority of SOX2 positive GSCs remaining in the As $\mathrm{O}_{3}$-treated xenografts were also PML positive. 
NSTCs show differential sensitivity to $\mathrm{As}_{2} \mathrm{O}_{3}$ treatment. While $\mathrm{As}_{2} \mathrm{O}_{3}$ treatment significantly inhibited GSC cell growth, the same dose of $\mathrm{As}_{2} \mathrm{O}_{3}$ treatment did not show a significant effect on matched NSTCs (Figure 6A and 6B, Supplementary Figure S4A and S4B). Consistently, no induction of the cleaved PARP (the apoptotic marker) was observed in NSTCs after $\mathrm{As}_{2} \mathrm{O}_{3}$ treatment (Figure 6C, middle panel), but the same $\mathrm{As}_{2} \mathrm{O}_{3}$ treatment markedly induced the cleaved PARP and apoptosis in GSCs (Figure $2 \mathrm{~A}-2 \mathrm{C})$. Interestingly, $\mathrm{As}_{2} \mathrm{O}_{3}$ treatment also reduced PML protein levels in NSTCs (Figure 6C, Supplementary Figure S4C) but did not show effect on cell growth of NSTCs. Taken together, the differential response of GSCs and NSTCs to the $\mathrm{As}_{2} \mathrm{O}_{3}$-induced PML reduction and the different PML distribution in these cell populations implicated that PML may have distinct functions via different downstream effectors in GSCs and NSTCs.

\section{c-Myc is the downstream effector of PML in the GSC maintenance}

Differential response of GSCs and NSTCs to $\mathrm{As}_{2} \mathrm{O}_{3}$ treatment prompted us to explore the downstream effector of PML in GSCs. As a time course treatment of GSCs with $\mathrm{As}_{2} \mathrm{O}_{3}$ resulted in gradual decrease of c-Myc (Figure 2A and 2B), the downregulation of c-Myc after $\mathrm{As}_{2} \mathrm{O}_{3}$-induced PML degradation suggested that c-Myc may be in the downstream of PML (Figure 2A and 2B). Previous studies showed that depletion of c-Myc in GSCs caused severe cell death [40], which is consistent with the phenotypes caused by $\mathrm{As}_{2} \mathrm{O}_{3}$ treatment. Moreover, c-Myc is preferentially expressed in GSCs relative to NSTCs [41], whereas $\mathrm{As}_{2} \mathrm{O}_{3}$ treatment showed no detectable effect on NSTCs expressing low level of intrinsic c-Myc protein (Supplementary Figure S4C). These facts indicate that c-Myc is a potential effector of PML in GSCs in response to $\mathrm{As}_{2} \mathrm{O}_{3}$ treatment. As PML has been shown to be a major target of $\mathrm{As}_{2} \mathrm{O}_{3}$ in cancer stem cells in leukemia [31], we sought to determine the regulatory relationship between PML and c-Myc in GSCs. Knockdown of PML by shRNA resulted in a marked decrease of c-Myc protein levels in GSCs (Figure 6D). Furthermore, ubiquitination assay demonstrated that disruption of PML dramatically increased poly-ubiquitination of $\mathrm{c}-\mathrm{Myc}$ protein and reduced c-Myc levels in GSCs (Figure 6E, Supplementary Figure S4D), suggesting that PML is required for c-Myc stabilization in GSCs. As c-Myc has been shown to interact with PML $[38,42]$, it's likely that the interaction between PML and c-Myc prevents ubiquitinationmediated degradation of c-Myc. Given that c-Myc is an important downstream effector of PML, the expression of c-Myc in GSCs in response to $\mathrm{As}_{2} \mathrm{O}_{3}$ treatment was further studied in vivo. Immunohistochemical staining of the GSC-derived intracranial xenografts with or without $\mathrm{As}_{2} \mathrm{O}_{3}$ treatment showed a marked reduction of c-Myc protein levels in the majority of tumor cells after $\mathrm{As}_{2} \mathrm{O}_{3}$ treatment, indicating c-Myc as a downstream effector of $\mathrm{As}_{2} \mathrm{O}_{3}$ treatment in GBM tumors (Figure 6F and 6G, Supplementary Figure S4E and S4F). Moreover, transient overexpression of c-Myc-GFP partially rescued the growth inhibition caused by $\mathrm{As}_{2} \mathrm{O}_{3}$ treatment in GSCs (Figure 7A). Immunofluorescent analysis indicated that GSCs overexpressing c-Myc-GFP had less apoptosis after $\mathrm{As}_{2} \mathrm{O}_{3}$ treatment (Figure 7B and 7C), highlighting the importance of c-Myc in mediating GSC resistance to $\mathrm{As}_{2} \mathrm{O}_{3}$ treatment. Collectively, these data demonstrated that $\mathrm{As}_{2} \mathrm{O}_{3}$ treatment destabilizes PML and c-Myc, which in turn impairs GSC maintenance, supporting that PML and its effector c-Myc are critical for the maintenance of the stem cell-like phenotype and tumorigenic potential of GSCs. Further investigations are required to unveil the detailed mechanisms underlying the regulation of PML on c-Myc stability.

\section{DISCUSSION}

The high frequency of tumor recurrence in GBM patients highlights the emergent requirement for drugs targeting glioma stem cells that are believed to be responsible for therapeutic resistance and tumor propagation. Our study suggests $\mathrm{As}_{2} \mathrm{O}_{3}$ as a potent drug preferentially targeting GSCs in GBM tumors. As a FDA approved drug for leukemia treatment, $\mathrm{As}_{2} \mathrm{O}_{3}$ has a long history in clinical practices with minor and contemporary side effects [24, 43]. Furthermore, compared with temozolomide, bevacizumab and other expensive drugs, $\mathrm{As}_{2} \mathrm{O}_{3}$ is an affordable drug with minimal economic concerns and can benefit the maximum number of GBM patients. A study in mice has demonstrated that $\mathrm{As}_{2} \mathrm{O}_{3}$ is able to enter brain [44]. Although the infusion and efficiency of $\mathrm{As}_{2} \mathrm{O}_{3}$ in human brain tumors remained to be further determined, it's likely that $\mathrm{As}_{2} \mathrm{O}_{3}$ as a small molecular drug can pass through the blood brain barrier to inhibit GBM tumor growth by targeting GSCs in human brains. $\mathrm{As}_{2} \mathrm{O}_{3}$ may have a concentration gradient in vivo and tumor cells will be killed only with the effective concentrations. However, $\mathrm{As}_{2} \mathrm{O}_{3}$ did inhibit orthotopic tumor growth in nude mice and thus showed its potential in treating GBMs. In addition, the increased vascular permeability in GBMs relative to normal brain tissues may benefit the $\mathrm{As}_{2} \mathrm{O}_{3}$ infusion in the tumor region. Thus, a suitable $\mathrm{As}_{2} \mathrm{O}_{3}$ dosage could exert the maximal inhibitory effect on tumor with minimal side effects on normal brain tissues.

We have demonstrated that $\mathrm{As}_{2} \mathrm{O}_{3}$ treatment potently induced apoptosis of GSCs but showed little effect on matched NSTCs. The differential sensitivity of GSCs and NSTCs in response to $\mathrm{As}_{2} \mathrm{O}_{3}$ treatment may be ascribed to the destabilization of the GSC transcriptional factor c-Myc induced by $\mathrm{As}_{2} \mathrm{O}_{3}$-triggered PML degradation. c-Myc is 

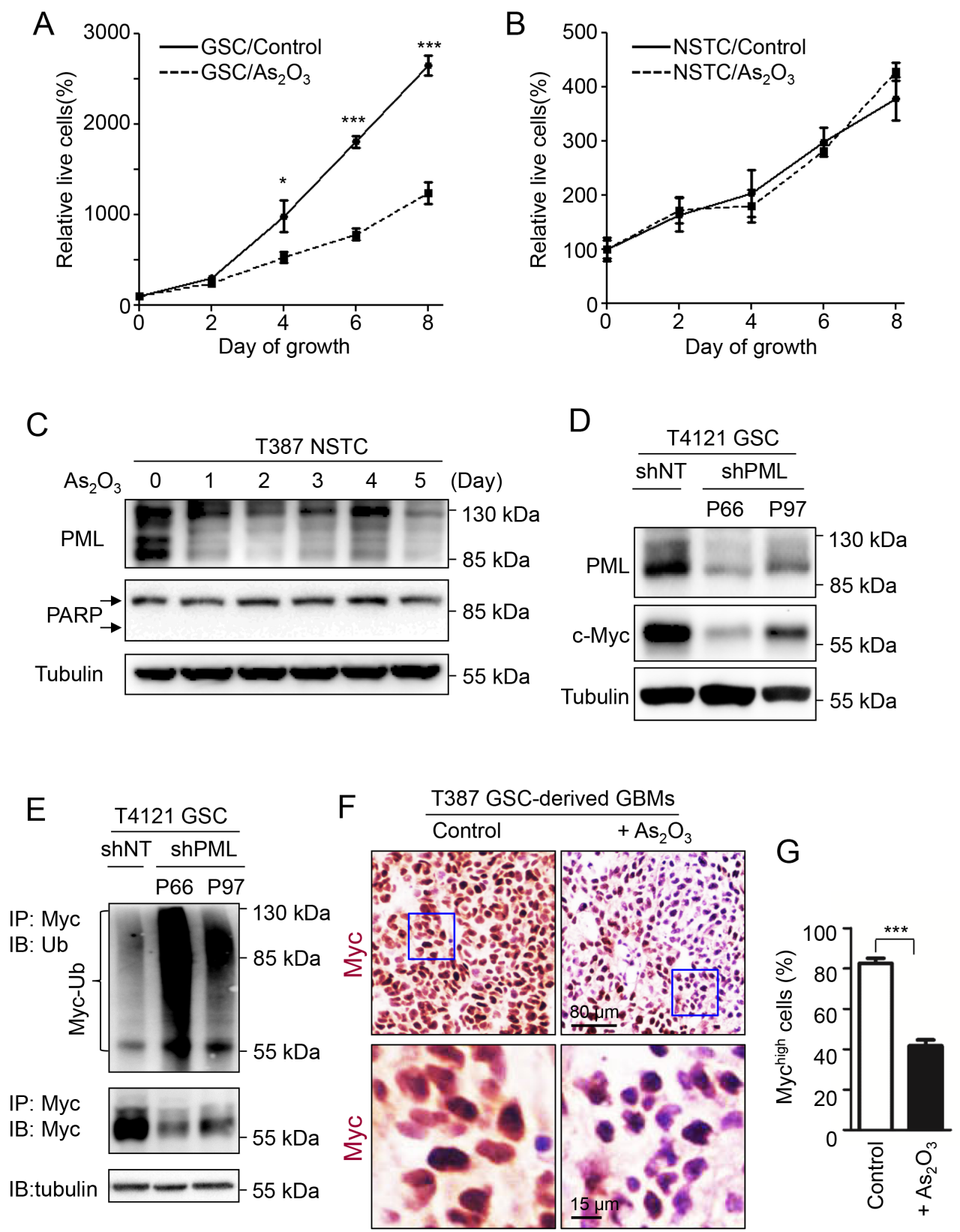

Figure 6: c-Myc is the downstream effector of PML in GSCs that associates with the GSC-preferential effects of $\mathrm{As}_{2} \mathbf{O}_{3}$. A, B. Cell growth curves of T387 GSCs (A) and matched NSTCs (B) in response to $\mathrm{As}_{2} \mathrm{O}_{3}$ treatment. 2,000 GSCs or NSTCs were planted in each well of 96 well plates and then treated with $1 \mu \mathrm{M} \mathrm{As}_{2} \mathrm{O}_{3}$ or vehicle control $(0.01 \mathrm{~N} \mathrm{NaOH})$. Cell titer was determined by the Glo luminescent cell viability assay kit (Promega) at the indicated time points. $\mathrm{As}_{2} \mathrm{O}_{3}$ treatment significantly inhibited cell growth of GSCs but not matched NSTCs. ${ }^{*} p<0.05 ; * * *<0.001$ (mean \pm s.e.m.; two tailed unpaired $t$-test). C. Immunoblot analysis of NSTCs treated with $\mathrm{As}_{2} \mathrm{O}_{3}$ for varied duration. $\mathrm{As}_{2} \mathrm{O}_{3}$ treatment resulted in reduced PML protein but did not induce the cleaved PARP, a marker of apoptosis. D. Immunoblot analysis of PML and c-Myc after PML knockdown by shPML (P66 or P97) in GSCs. Disruption of endogenous PML by shPML resulted in a substantial decrease in c-Myc protein levels in GSCs (T4121). E. Ubiquitination assay of c-Myc in GSCs transduced with shPML (P66 or P97) or shNT control. GSCs (T4121) were transfected with shPML or shNT through lentiviral infection for 36 hours, and then treated with $20 \mu \mathrm{M}$ MG132 for 6 hours. Cell lysate was subjected to immunoprecipitation with the anti-c-Myc agarose beads, and the c-Myc poly-ubiquitination status was determined with anti-ubiquitin antibody. A significant increase in c-Myc polyubiquitination and a decrease of c-Myc protein levels were detected in cells transduced with shPML relative to the shNT control. Tubulin was used as the internal control for the input of immunoprecipitation (lower panel). F. Immunohistochemistry of c-Myc to determine the population of cells with high c-Myc expression in T387 GSC-derived xenografts after $\mathrm{As}_{2} \mathrm{O}_{3}$ treatment. Sections of GSC-derived xenografts were stained with the antibody against c-Myc. Xenografts treated with $\mathrm{As}_{2} \mathrm{O}_{3}$ showed much weaker c-Myc staining (in brown) than those treated with the vehicle control. G. Bar graphs showing the population of cells with high c-Myc expression in the xenografts treated with $\mathrm{As}_{2} \mathrm{O}_{3}$ or vehicle control. A significant reduction of cells with high c-Myc expression was detected in $\mathrm{As}_{2} \mathrm{O}_{3}$-treated xenografts relative to the control xenografts. ${ }^{* * *} p<0.001$ (mean \pm s.e.m.; two tailed unpaired $t$-test). 
A

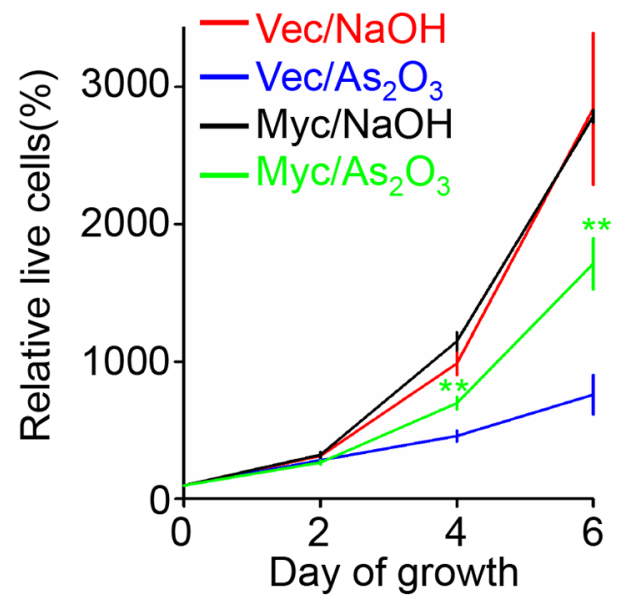

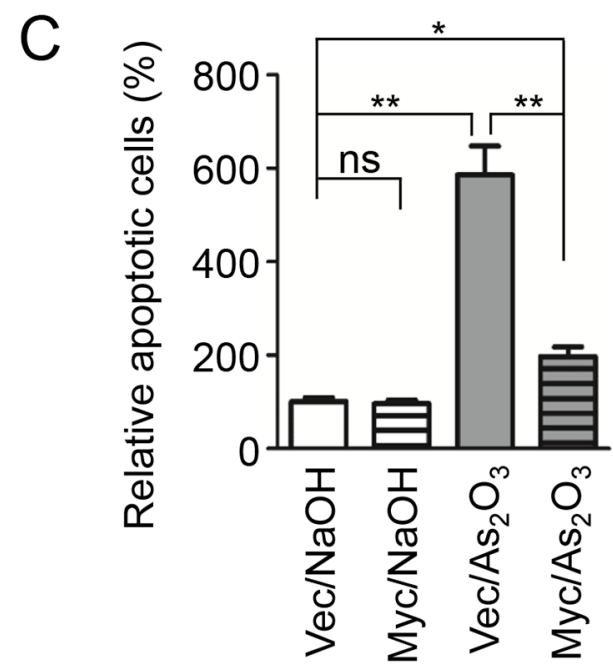
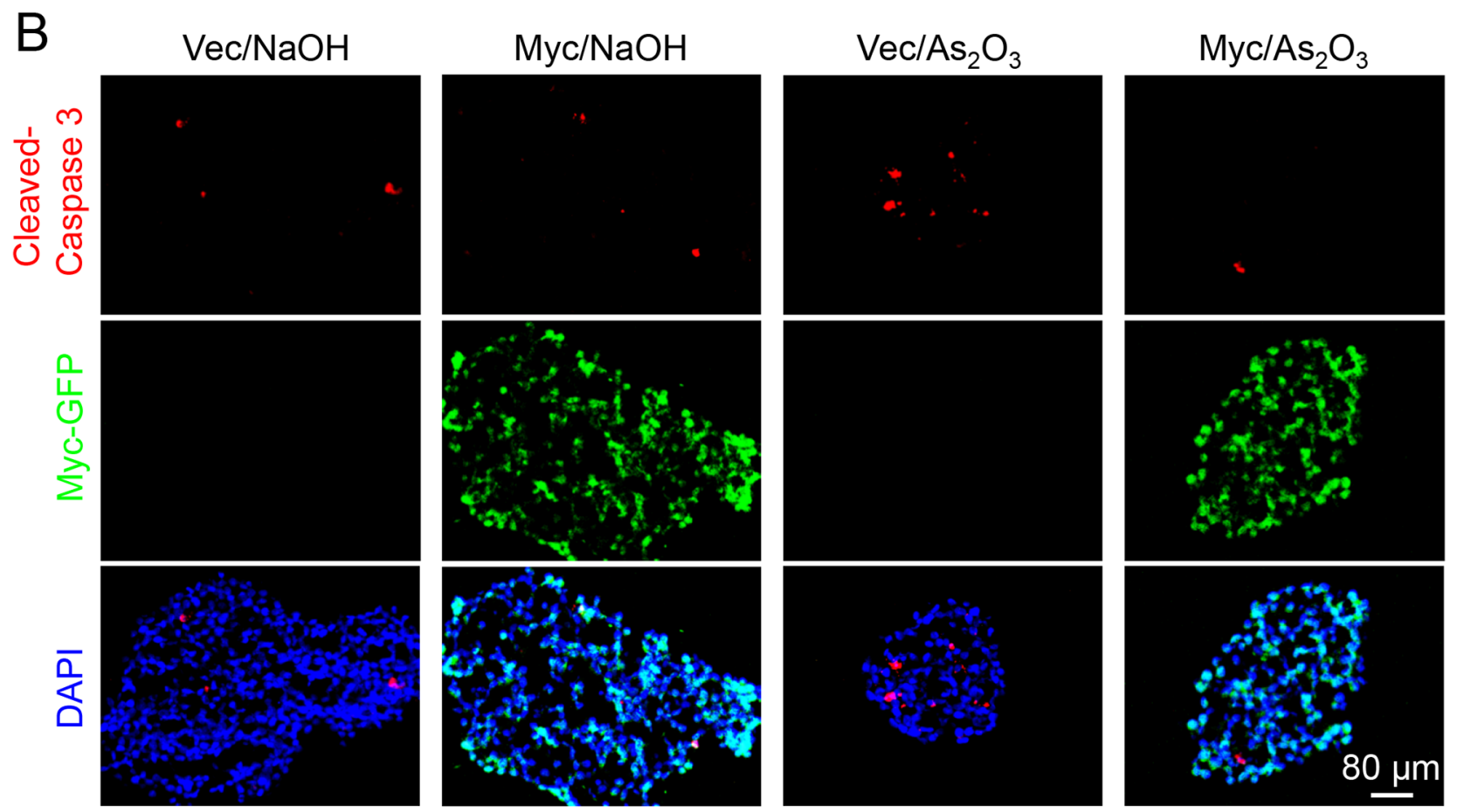

Figure 7: Overexpression of c-Myc partially rescued the inhibitory effects of $\mathbf{A s}_{2} \mathbf{O}_{3}$ on GSCs. A. Cell titer assays of GSCs overexpressing c-Myc-GFP or control vector. T387 GSCs were infected with c-Myc-GFP or control lentiviruses. 48 hours after infection, cells were planted into 96 well plates at the concentration of 2,000 cells per well. Cells were then treated with $1 \mu \mathrm{M} \mathrm{As} \mathrm{O}_{3}$ or $0.01 \mathrm{~N} \mathrm{NaOH}$. Cell growth was monitor at the indicated time point with the cell titer Glo luminescent cell viability assay kit. A partial rescue was observed in GSCs infected with c-Myc-GFP in response to $\mathrm{As}_{2} \mathrm{O}_{3}$ treatment. ${ }^{*} p<0.01$ (mean \pm s.e.m.; two tailed unpaired $t$-test). B. Immunofluorescent staining of apoptosis in GSC spheres. T387 GSCs were cultured in 12-well plates at the concentration of 500,000 cells per well when infected with c-Myc-GFP or control lentiviruses. 48 hours after infection, GSC spheres were fixed with 4\% PFA. Frozen sections of the spheres were stained with the antibody against the apoptotic marker cleaved Caspase-3 (red). Exogenous c-Myc expression was monitored by GFP signal (green). $\mathrm{As}_{2} \mathrm{O}_{3}$ treatment resulted in a significant increase in cleaved Caspase-3 signal in control infected GSC spheres. However, c-Myc-GFP overexpressing GSC spheres showed significant fewer cleaved Caspase-3 staining relative to the control spheres. C. Bar graph to show the cleaved Caspase-3 staining in control or c-Myc-GFP overexpressing xenografts treated with $\mathrm{As}_{2} \mathrm{O}_{3}$ or NaOH. Overexpression of c-Myc-GFP partially rescued the apoptosis induced by $\mathrm{As}_{2} \mathrm{O}_{3}$ treatment. ${ }^{*} p<0.05 ; * * p<0.01$ (mean \pm s.e.m.; two tailed unpaired $t$-test).

a pivotal regulator controlling multiple cellular activities [45]. c-Myc is highly expressed in GSCs relative to NSTCs or normal neural progenitor cells, which provides the molecular basis for the discrimination between GSCs and NSTCs [40, 41]. However, the molecular mechanisms underlying the stabilization of c-Myc by PML in GSCs remain unclear. Previous reports described the partially localization of c-Myc in nuclear bodies along with the 
physical interaction between c-Myc and PML [38, 42]. It is possible that the nuclear bodies may sequester $\mathrm{c}-\mathrm{Myc}$ and prevent c-Myc from the ubiquitination-mediated degradation, thereby maintain high c-Myc protein level in GSCs. On the other hand, PML nuclear bodies are believed to be transcriptional hot spots. It has been shown that PML affects transcription of several c-Myc target genes [42]. From this aspect, degradation of $\mathrm{PML}$ by $\mathrm{As}_{2} \mathrm{O}_{3}$ may affect the c-Myc regulated transcriptome in GSCs which in turn impairs the maintenance of GSCs. Although c-Myc is barely detected in neural progenitor cells, PML is found to regulate the fate of neural progenitor cells in mouse developing neocortex through affecting the subcellular distribution of the retinoblastoma protein and the protein phosphatase $1 \alpha$ [46]. The role of PML in human neural progenitor cells remains unknown. In vitro treatment of human neural progenitor cell lines with $\mathrm{As}_{2} \mathrm{O}_{3}$ reduced PML protein levels without obvious effects on cell growth (Supplementary Figure S5). Thus, PML in normal and tumor stem cells has distinct functions, which are likely to be mediated by different PML downstream pathways.

In previous reports using in vitro cultured GBM tumour-spheres, the inhibition of Notch downstream factors was observed after $\mathrm{As}_{2} \mathrm{O}_{3}$ treatment [32]. However, there's no evidence showing that Notch pathway could directly mediate the effects of $\mathrm{As}_{2} \mathrm{O}_{3}$ stimulation. On the contrary, PML is widely recognized as the major and immediate target of $\mathrm{As}_{2} \mathrm{O}_{3}[26,28]$. In fact, PML is involved in regulation of several key factors in stem cells. $\mathrm{PML} / \mathrm{mTOR}$ axis plays a critical role in the maintenance of hematopoietic stem cells [31]. Interestingly, PML is also reported to contribute to GBM resistance to mTOR targeted therapies [47], suggesting its involvement in GBM tumor progression. In addition, PML expression is required for survival of hematopoietic stem cells and breast cancer stem cells through activation of PPAR- $\delta$ pathway $[48,49]$. Moreover, multiple key transcriptional factors important for stem cell maintenance, including Oct4, Nanog, Stat3 and REST, have been shown to be associated with PML in stem cells [50-52]. Even the Notch pathway may be regulated by PML [53]. Thus, PML may support GSCs through multiple pathways, and degradation of $\mathrm{PML}$ induced by $\mathrm{As}_{2} \mathrm{O}_{3}$ treatment has complex destructive effects on GSC maintenance.

PML has seven known major isoforms, each containing some transcriptional variants and the corresponding protein products $[36,54]$. Our results suggested expression of multiple PML isoforms in GSCs (Figure 2A and 2B). However, introduction of shRNA resistant PMLI and PMLIV, either respectively or in combination, could not rescue the GSCs depleted of endogenous PML proteins (data not shown). Since multiple, if not all, PML isoforms participate in nuclear body formation [37, 39], plural PML isoforms may function as a complex in GSCs and each of these isoforms is indispensable for GSC survival. In the meantime, PML has several kinds of post-translational modifications including sumoylation, phosphorylation, ubiquitination, and acetylation [27-29, 55]. It would be interesting to determine whether these modifications are relevant to targeting of GSCs by $\mathrm{As}_{2} \mathrm{O}_{3}$.

In summary, we found that $\mathrm{As}_{2} \mathrm{O}_{3}$ treatment can efficiently target GSCs in vitro and in vivo. Such effects can be mainly ascribed to the $\mathrm{As}_{2} \mathrm{O}_{3}$-induced PML reduction and subsequent c-Myc degradation mediated by poly-ubiquitination. Our findings suggest a clinical application of the well-known anti-leukemia drug $\mathrm{As}_{2} \mathrm{O}_{3}$ in treating the malignant brain tumors by targeting glioma stem cells.

\section{MATERIALS AND METHODS}

\section{Isolation and culture of glioma stem cells (GSCs)}

GSCs were isolated from primary GBM tumors or subcutaneous xenografts as previously described $[3,14,41,56,57]$. De-identified GBM surgical specimens were collected from Cleveland Clinic Brain Tumor and Neuro-Oncology Center in accordance with an Institutional Review Board-approved protocol. GBM tumor cells were dissociated with the Papain Dissociation System (Worthington Biochemical) and GSCs were sorted by fluorescence-activated cell sorting (FACS) using two GSC surface markers (CD15/CD133). GSCs were validated for their capacity of serial sphere formation, in vitro induction of differentiation and in vivo tumor propagation as previously described $[3,14,57]$. NSTCs were sorted $\mathrm{CD} 133^{-} / \mathrm{CD} 15^{-}$cells from the same tumor.

\section{Establishment of GSC-derived orthotopic GBM xenografts and $\mathrm{As}_{2} \mathrm{O}_{3}$ treatment}

Orthotopic GBM xenografts were derived from intracranial transplantation of GSCs as described $[3,14$, 57]. Athymic female immunocompromised C57/BL6 mice of 4-6 weeks (Charles River Laboratories) were used for animal experiments. GSCs transduced with luciferase and/or shPML (P66 or P97) or shNT were injected into the right cerebral cortex at a depth of $3.5 \mathrm{~mm}$. Mice were monitored by bioluminescent imaging or maintained until manifestation of neurological signs. Mouse KaplanMeier survival curves were made with GraphPad Prism 5 software by using Logrank two-tail analysis. All animal protocols were approved by the Animal Research Committee of the Cleveland Clinic, and all animals were housed in the Association for the Assessment and Accreditation of Laboratory Animal Care-accredited animal facility of the Cleveland Clinic.

Treatment of mice with $\mathrm{As}_{2} \mathrm{O}_{3}$ (Sigma-Aldrich, 202673-5G) was started on the fourth day after intracranial implantation of GSCs expressing luciferase. Mice were treated with $\mathrm{As}_{2} \mathrm{O}_{3}$ at a dosage of $5 \mu \mathrm{g} / \mathrm{g}$ (in $0.01 \mathrm{M} \mathrm{NaOH}$ ) 
of body weight daily through intraperitoneal injection throughout the period of tumor growth. The control group mice were treated with the same volume of vehicle control $(0.01 \mathrm{M} \mathrm{NaOH})$ per day. The similar dosage of $\mathrm{As}_{2} \mathrm{O}_{3}$ $(5 \mu \mathrm{g} / \mathrm{g} / \mathrm{IP} /$ daily) applied in this treatment has been used for treating leukemia in mice by other published studies $[33,34]$. No sign of toxicity was observed in $\mathrm{As}_{2} \mathrm{O}_{3}$ treated mice other than a slight weight loss.

\section{Immunoblot analysis}

Immunoblotting was performed as previously described [9, 56-58]. Briefly, cells were lysed in RIPA buffer $(50 \mathrm{mM}$ Tris $\mathrm{HCl}$ pH7.4, $150 \mathrm{mM} \mathrm{NaCl}, 2 \mathrm{mM}$ EDTA pH8.0, 1\% NP-40, 0.1\% SDS, 10 mM NaF, 20 mM beta-Glycerophosphate, $1 \mathrm{mM} \mathrm{Na} \mathrm{VO}_{3}, 1 \mathrm{mM}$ PMSF, protease inhibitor cocktail) and subjected to SDS-PAGE. Proteins were transferred to PVDF membrane (Biorad), blocked by $5 \%$ milk for 30 minutes, and incubated with primary antibody overnight at $4^{\circ} \mathrm{C}$. Membranes were washed with TBST for 3 times and incubated with secondary antibody for 2 hours at room temperature. Membranes were then washed with TBST for 3 times and subjected to chemiluminescent substrate (Thermo Scientific). Signals were detected with ChemiDoc XRS + Imager (Biorad).

\section{Immunofluorescence and immunohistochemistry}

Immunofluorescent staining and immunohistochemistry (IHC) were performed as described [9, 56-58]. For cultured GSCs, cells were attached to the hES-Matrix coated coverslips before staining. For immunofluorescence, Alexa-conjugated secondary (Life Technologies) antibodies were applied. For immunohistochemistry, biotinylated secondary antibodies were used together with the Vectastain ABC kit and the DAB kit (Vector Laboratories) per manufacturer's instructions.

\section{Antibodies and reagents}

PML antibodies were purchased from Santa Cruz (sc-966) for immunofluorescent staining, or from Bethyl (A301-167A) for immunoblotting. c-Myc antibody (sc-40) and Sox2 antibody (sc-17320) were purchased from Santa Cruz. PARP antibody (9542) and cleaved Caspase-3 antibody (9661S) were from Cell Signaling. Glut1 antibody was from Thermo Scientific (PA1-37782). Arsenic trioxide was purchased from Sigma (202673-5G) and the stock solution was prepared at $100 \mathrm{mM}$ as instructed by manufacturer.

\section{Production of shRNA Lentiviruses and knockdown}

PML shRNA (shPML) and the no-targeting shRNA (shNT) control lentiviral constructs were purchased from Sigma (TRCN0000003866 for shPML-P66, TRCN0000355997 for shPML-P97, SHC002 for shNT). For virus package, 293FT cells were transfected with lentiviral construct along with psPAX2 and VSVG. 48-72 hours after transfection, viral supernatants were collected and transduced into cells. Infected cells were selected with $1 \mu \mathrm{g} / \mathrm{mL}$ puromycin for 2 days to get rid of uninfected cells.

\section{Ubiquitination assay}

Ubiquitination assay was performed as previously described [58]. GSCs overexpressing shNT or shPML shRNAs were treated with the proteasome inhibitor MG132 (20 $\mu \mathrm{M}$, Sigma-Aldrich, C2211-5MG) for 6 hours and then lysed in TritonX-100 lysis buffer, immunoprecipitated with anti-Myc agarose affinity gel (Sigma-Aldrich, A7470-1ML) and immunoblotted with an anti-ubiquitin (Biolegend, 646301) or anti-c-Myc antibody (Santa Cruz, sc-40). Briefly, cell lysates $(300 \mu \mathrm{g}$ of total protein) were incubated with $15 \mu \mathrm{L}$ anti-Myc conjugated agarose gel with constant rotation overnight at $4^{\circ} \mathrm{C}$. Immunocomplexes were washed three times with ice-cold $0.3 \%$ Triton X-100 in PBS buffer and eluted in loading buffer by boiling for $10 \mathrm{~min}$, and then analyzed by immunoblotting. Proteins were resolved on NuPAGE Novex 4-12\% Bis-Tris gels (Invitrogen, NP0322BOX), blotted onto polyvinylidene membranes and probed by antibodies specific to ubiquitin and c-Myc.

\section{Statistical analysis}

The level of significance was determined by a twotailed un-paired Student's $t$-test (bar graphs) or analysis of variance with $\alpha=0.05$ (survival curves), and then analyzed with GraphPad Prism 5 software. All quantitative data presented are the mean \pm s.e.m. from at least three samples or experiments per data point.

\section{ACKNOWLEDGMENTS AND FUNDING}

We thank the Brain Tumor and Neuro-Oncology Centers at Cleveland Clinic for providing GBM surgical specimens for this study.

\section{CONFLICTS OF INTEREST}

All authors declare no potential conflict of interest.

\section{GRANT SUPPORT}

This work was supported by the Cleveland Clinic Foundation and the NIH R01 grants (NS070315 and CA184090) to S. Bao. 


\section{REFERENCES}

1. DeAngelis LM. Brain tumors. The New England journal of medicine. 2001; 344:114-123.

2. Singh SK, Clarke ID, Terasaki M, Bonn VE, Hawkins C, Squire J, Dirks PB. Identification of a cancer stem cell in human brain tumors. Cancer research. 2003; 63: 5821-5828.

3. Bao S, Wu Q, McLendon RE, Hao Y, Shi Q, Hjelmeland AB, Dewhirst MW, Bigner DD, Rich JN. Glioma stem cells promote radioresistance by preferential activation of the DNA damage response. Nature. 2006; 444:756-760.

4. Calabrese C, Poppleton H, Kocak M, Hogg TL, Fuller C, Hamner B, Oh EY, Gaber MW, Finklestein D, Allen M, Frank A, Bayazitov IT, Zakharenko SS, Gajjar A, Davidoff A, Gilbertson RJ. A perivascular niche for brain tumor stem cells. Cancer cell. 2007; 11:69-82.

5. Pietras A, Katz AM, Ekstrom EJ, Wee B, Halliday JJ, Pitter KL, Werbeck JL, Amankulor NM, Huse JT, Holland EC. Osteopontin-CD44 signaling in the glioma perivascular niche enhances cancer stem cell phenotypes and promotes aggressive tumor growth. Cell stem cell. 2014; 14:357-369.

6. Wei J, Barr J, Kong LY, Wang Y, Wu A, Sharma AK, Gumin J, Henry V, Colman H, Sawaya R, Lang FF, Heimberger AB. Glioma-associated cancer-initiating cells induce immunosuppression. Clinical cancer research: an official journal of the American Association for Cancer Research. 2010; 16:461-473.

7. Chen J, Li Y, Yu TS, McKay RM, Burns DK, Kernie SG, Parada LF. A restricted cell population propagates glioblastoma growth after chemotherapy. Nature. 2012; 488:522-526.

8. Huang Z, Cheng L, Guryanova OA, Wu Q, Bao S. Cancer stem cells in glioblastoma - molecular signaling and therapeutic targeting. Protein \& cell. 2010; 1:638-655.

9. Cheng L, Wu Q, Huang Z, Guryanova OA, Huang Q, Shou W, Rich JN, Bao S. L1CAM regulates DNA damage checkpoint response of glioblastoma stem cells through NBS1. The EMBO journal. 2011; 30:800-813.

10. Hambardzumyan D, Becher OJ, Rosenblum MK, Pandolfi PP, Manova-Todorova K, Holland EC. PI3K pathway regulates survival of cancer stem cells residing in the perivascular niche following radiation in medulloblastoma in vivo. Genes \& development. 2008; 22:436-448.

11. Bleau AM, Hambardzumyan D, Ozawa T, Fomchenko EI, Huse JT, Brennan CW, Holland EC. PTEN/PI3K/Akt pathway regulates the side population phenotype and ABCG2 activity in glioma tumor stem-like cells. Cell stem cell. 2009; 4:226-235.

12. Tamura K, Aoyagi M, Wakimoto H, Ando N, Nariai T, Yamamoto M, Ohno K. Accumulation of CD133-positive glioma cells after high-dose irradiation by Gamma
Knife surgery plus external beam radiation. Journal of neurosurgery. 2010; 113:310-318.

13. Kim MJ, Kim RK, Yoon CH, An S, Hwang SG, Suh Y, Park MJ, Chung HY, Kim IG, Lee SJ. Importance of PKCdelta signaling in fractionated-radiation-induced expansion of glioma-initiating cells and resistance to cancer treatment. Journal of cell science. 2011; 124:3084-3094.

14. Cheng L, Huang $\mathrm{Z}$, Zhou W, Wu Q, Donnola S, Liu JK, Fang X, Sloan AE, Mao Y, Lathia JD, Min W, McLendon RE, Rich JN, Bao S. Glioblastoma stem cells generate vascular pericytes to support vessel function and tumor growth. Cell. 2013; 153:139-152.

15. Ruiz-Ontanon P, Orgaz JL, Aldaz B, Elosegui-Artola A, Martino J, Berciano MT, Montero JA, Grande L, Nogueira L, Diaz-Moralli S, Esparis-Ogando A, VazquezBarquero A, Lafarga M, Pandiella A, Cascante M, Segura V, et al. Cellular plasticity confers migratory and invasive advantages to a population of glioblastoma-initiating cells that infiltrate peritumoral tissue. Stem cells. 2013; 31:1075-1085.

16. Bao S, Wu Q, Sathornsumetee S, Hao Y, Li Z, Hjelmeland AB, Shi Q, McLendon RE, Bigner DD, Rich JN. Stem cell-like glioma cells promote tumor angiogenesis through vascular endothelial growth factor. Cancer research. 2006; 66:7843-7848.

17. Kobayashi $\mathrm{K}$, Takahashi $\mathrm{H}$, Inoue $\mathrm{A}$, Harada $\mathrm{H}$, Toshimori S, Kobayashi Y, Goto K, Sugimoto K, Yano H, Ohnishi T, Tanaka J. Oct-3/4 promotes migration and invasion of glioblastoma cells. Journal of cellular biochemistry. 2012; 113:508-517.

18. McNamara MG, Lwin Z, Jiang H, Chung C, Millar BA, Sahgal A, Laperriere N, Mason WP. Conditional probability of survival and post-progression survival in patients with glioblastoma in the temozolomide treatment era. Journal of neuro-oncology. 2014; 117:153-160.

19. Auffinger B, Tobias AL, Han Y, Lee G, Guo D, Dey M, Lesniak MS, Ahmed AU. Conversion of differentiated cancer cells into cancer stem-like cells in a glioblastoma model after primary chemotherapy. Cell death and differentiation. 2014; 21:1119-1131.

20. Hamerlik P, Lathia JD, Rasmussen R, Wu Q, Bartkova J, Lee M, Moudry P, Bartek J Jr., Fischer W, Lukas J, Rich JN, Bartek J. Autocrine VEGF-VEGFR2-Neuropilin-1 signaling promotes glioma stem-like cell viability and tumor growth. The Journal of experimental medicine. 2012; 209:507-520.

21. Keunen O, Johansson M, Oudin A, Sanzey M, Rahim SA, Fack F, Thorsen F, Taxt T, Bartos M, Jirik R, Miletic H, Wang J, Stieber D, Stuhr L, Moen I, Rygh CB, et al. AntiVEGF treatment reduces blood supply and increases tumor cell invasion in glioblastoma. Proceedings of the National Academy of Sciences of the United States of America. 2011; 108:3749-3754.

22. Li Z, Bao S, Wu Q, Wang H, Eyler C, Sathornsumetee S, Shi Q, Cao Y, Lathia J, McLendon RE, Hjelmeland AB, 
Rich JN. Hypoxia-inducible factors regulate tumorigenic capacity of glioma stem cells. Cancer cell. 2009; 15:501-513.

23. Piao Y, Liang J, Holmes L, Zurita AJ, Henry V, Heymach JV, de Groot JF. Glioblastoma resistance to anti-VEGF therapy is associated with myeloid cell infiltration, stem cell accumulation, and a mesenchymal phenotype. Neurooncology. 2012; 14:1379-1392.

24. Lengfelder E, Hofmann WK, Nowak D. Impact of arsenic trioxide in the treatment of acute promyelocytic leukemia. Leukemia. 2012; 26:433-442.

25. de The H, Chen Z. Acute promyelocytic leukaemia: novel insights into the mechanisms of cure. Nature reviews Cancer. 2010; 10:775-783.

26. Zhang XW, Yan XJ, Zhou ZR, Yang FF, Wu ZY, Sun HB, Liang WX, Song AX, Lallemand-Breitenbach V, Jeanne M, Zhang QY, Yang HY, Huang QH, Zhou GB, Tong JH, Zhang Y, et al. Arsenic trioxide controls the fate of the PML-RARalpha oncoprotein by directly binding PML. Science. 2010; 328:240-243.

27. Lallemand-Breitenbach V, Jeanne M, Benhenda S, Nasr R, Lei M, Peres L, Zhou J, Zhu J, Raught B, de The H. Arsenic degrades PML or PML-RARalpha through a SUMOtriggered RNF4/ubiquitin-mediated pathway. Nature cell biology. 2008; 10:547-555.

28. Tatham MH, Geoffroy MC, Shen L, Plechanovova A, Hattersley N, Jaffray EG, Palvimo JJ, Hay RT. RNF4 is a poly-SUMO-specific E3 ubiquitin ligase required for arsenic-induced PML degradation. Nature cell biology. 2008; 10:538-546.

29. Hayakawa F, Privalsky ML. Phosphorylation of PML by mitogen-activated protein kinases plays a key role in arsenic trioxide-mediated apoptosis. Cancer cell. 2004; 5:389-401.

30. Nasr R, Guillemin MC, Ferhi O, Soilihi H, Peres L, Berthier C, Rousselot P, Robledo-Sarmiento M, LallemandBreitenbach V, Gourmel B, Vitoux D, Pandolfi PP, Rochette-Egly C, Zhu J, de The H. Eradication of acute promyelocytic leukemia-initiating cells through PML-RARA degradation. Nature medicine. 2008; 14:1333-1342.

31. Ito K, Bernardi R, Morotti A, Matsuoka S, Saglio G, Ikeda Y, Rosenblatt J, Avigan DE, Teruya-Feldstein J, Pandolfi PP. PML targeting eradicates quiescent leukaemiainitiating cells. Nature. 2008; 453:1072-1078.

32. Ding D, Lim KS, Eberhart CG. Arsenic trioxide inhibits Hedgehog, Notch and stem cell properties in glioblastoma neurospheres. Acta neuropathologica communications. 2014; $2: 31$.

33. Rego EM, He LZ, Warrell RP Jr., Wang ZG, Pandolfi PP. Retinoic acid (RA) and As2O3 treatment in transgenic models of acute promyelocytic leukemia (APL) unravel the distinct nature of the leukemogenic process induced by the PML-RARalpha and PLZF-RARalpha oncoproteins.
Proceedings of the National Academy of Sciences of the United States of America. 2000; 97:10173-10178.

34. Jang M, Kim Y, Won H, Lim S, K RJ, Dashdorj A, Min YH, Kim SY, Shokat KM, Ha J, Kim SS. Carbonyl reductase 1 offers a novel therapeutic target to enhance leukemia treatment by arsenic trioxide. Cancer research. 2012; 72:4214-4224.

35. Yao XH, Ping YF, Chen JH, Xu CP, Chen DL, Zhang R, Wang JM, Bian XW. Glioblastoma stem cells produce vascular endothelial growth factor by activation of a G-protein coupled formylpeptide receptor FPR. The Journal of pathology. 2008; 215:369-376.

36. Bernardi R, Pandolfi PP. Structure, dynamics and functions of promyelocytic leukaemia nuclear bodies. Nature reviews Molecular cell biology. 2007; 8:1006-1016.

37. Fagioli M, Alcalay M, Tomassoni L, Ferrucci PF, Mencarelli A, Riganelli D, Grignani F, Pozzan T, Nicoletti I, Grignani F, Pelicci PG. Cooperation between the RING + B1-B2 and coiled-coil domains of PML is necessary for its effects on cell survival. Oncogene. 1998; 16:2905-2913.

38. Smith KP, Byron M, O'Connell BC, Tam R, Schorl C, Guney I, Hall LL, Agrawal P, Sedivy JM, Lawrence JB. c-Myc localization within the nucleus: evidence for association with the PML nuclear body. Journal of cellular biochemistry. 2004; 93:1282-1296.

39. Geng Y, Monajembashi S, Shao A, Cui D, He W, Chen Z, Hemmerich P, Tang J. Contribution of the C-terminal regions of promyelocytic leukemia protein (PML) isoforms II and V to PML nuclear body formation. The Journal of biological chemistry. 2012; 287:30729-30742.

40. Wang J, Wang H, Li Z, Wu Q, Lathia JD, McLendon RE, Hjelmeland AB, Rich JN. c-Myc is required for maintenance of glioma cancer stem cells. PloS one. 2008; 3:e3769.

41. Fang X, Huang Z, Zhou W, Wu Q, Sloan AE, Ouyang G, McLendon RE, Yu JS, Rich JN, Bao S. The zinc finger transcription factor ZFX Is required for maintaining the tumorigenic potential of glioblastoma stem cells. Stem cells. 2014; .

42. Cairo S, De Falco F, Pizzo M, Salomoni P, Pandolfi PP, Meroni G. PML interacts with Myc, and Myc target gene expression is altered in PML-null fibroblasts. Oncogene. 2005; 24:2195-2203.

43. Au WY, Kwong YL. Arsenic trioxide: safety issues and their management. Acta pharmacologica Sinica. 2008; 29:296-304.

44. Ma N, Sasoh M, Kawanishi S, Sugiura H, Piao F. Protection effect of taurine on nitrosative stress in the mice brain with chronic exposure to arsenic. Journal of biomedical science. 2010; 17:S7.

45. Dang CV. MYC on the path to cancer. Cell. 2012; 149:22-35. 
46. Regad T, Bellodi C, Nicotera P, Salomoni P. The tumor suppressor Pml regulates cell fate in the developing neocortex. Nature neuroscience. 2009; 12:132-140.

47. Iwanami A, Gini B, Zanca C, Matsutani T, Assuncao A, Nael A, Dang J, Yang H, Zhu S, Kohyama J, Kitabayashi I, Cavenee WK, Cloughesy TF, Furnari FB, Nakamura M, Toyama Y, et al. PML mediates glioblastoma resistance to mammalian target of rapamycin (mTOR)-targeted therapies. Proceedings of the National Academy of Sciences of the United States of America. 2013; 110: 4339-4344.

48. Ito K, Carracedo A, Weiss D, Arai F, Ala U, Avigan DE, Schafer ZT, Evans RM, Suda T, Lee CH, Pandolfi PP. A PML-PPAR-delta pathway for fatty acid oxidation regulates hematopoietic stem cell maintenance. Nature medicine. 2012; 18:1350-1358.

49. Carracedo A, Weiss D, Leliaert AK, Bhasin M, de Boer VC, Laurent G, Adams AC, Sundvall M, Song SJ, Ito K, Finley LS, Egia A, Libermann T, Gerhart-Hines Z, Puigserver $\mathrm{P}$, Haigis MC, et al. A metabolic prosurvival role for PML in breast cancer. The Journal of clinical investigation. 2012; 122:3088-3100.

50. Kawasaki A, Matsumura I, Kataoka Y, Takigawa E, Nakajima K, Kanakura Y. Opposing effects of PML and PML/RAR alpha on STAT3 activity. Blood. 2003; 101:3668-3673.

51. Liang J, Wan M, Zhang Y, Gu P, Xin H, Jung SY, Qin J, Wong J, Cooney AJ, Liu D, Songyang Z. Nanog and Oct4 associate with unique transcriptional repression complexes in embryonic stem cells. Nature cell biology. 2008; 10:731-739.

52. Zhang P, Pazin MJ, Schwartz CM, Becker KG, Wersto RP, Dilley CM, Mattson MP. Nontelomeric TRF2-REST interaction modulates neuronal gene silencing and fate of tumor and stem cells. Current biology: CB. 2008; 18:1489-1494.

53. Alcalay M, Meani N, Gelmetti V, Fantozzi A, Fagioli M, Orleth A, Riganelli D, Sebastiani C, Cappelli E, Casciari C, Sciurpi MT, Mariano AR, Minardi SP, Luzi L, Muller H, Di Fiore PP, et al. Acute myeloid leukemia fusion proteins deregulate genes involved in stem cell maintenance and DNA repair. The Journal of clinical investigation. 2003; 112:1751-1761.

54. Jensen K, Shiels C, Freemont PS. PML protein isoforms and the RBCC/TRIM motif. Oncogene. 2001; 20:7223-7233.

55. Hayakawa F, Abe A, Kitabayashi I, Pandolfi PP, Naoe T. Acetylation of PML is involved in histone deacetylase inhibitor-mediated apoptosis. The Journal of biological chemistry. 2008; 283:24420-24425.

56. Guryanova OA, Wu Q, Cheng L, Lathia JD, Huang Z, Yang J, MacSwords J, Eyler CE, McLendon RE, Heddleston JM, Shou W, Hambardzumyan D, Lee J, Hjelmeland AB, Sloan AE, Bredel M, et al. Nonreceptor tyrosine kinase BMX maintains self-renewal and tumorigenic potential of glioblastoma stem cells by activating STAT3. Cancer cell. 2011; 19:498-511.

57. Zhou W, Ke SQ, Huang Z, Flavahan W, Fang X, Paul J, Wu L, Sloan AE, McLendon RE, Li X, Rich JN, Bao S. Periostin secreted by glioblastoma stem cells recruits M2 tumour-associated macrophages and promotes malignant growth. Nature cell biology. 2015; 17:170-182.

58. Huang Z, Wu Q, Guryanova OA, Cheng L, Shou W, Rich JN, Bao S. Deubiquitylase HAUSP stabilizes REST and promotes maintenance of neural progenitor cells. Nature cell biology. 2011; 13:142-152. 